\title{
Starší a střední doba bronzová na Pavlovských vrších a v jejich okolí
}

\section{Early and Middle Bronze Age in the Pavlov Hills and in their surroundings}

\section{Aleš Navrátil}

\begin{abstract}
Abstrakt
Okolí Pavlovských vrchů má bohatou archeologickou historii a patři kjedněm z nejlépe probádaných oblastí u nás. Díky souborné publikaci všech známých archeologických aktivit souvisejících s prostorem výstavby novomlýnských nádrží je velká část informací o zdejších výzkumech přehledně dostupná. Naopak doposud nezveřejněny zůstaly bližší informace o výzkumech staroa středobronzových lokalit nacházejících se v samotném srdci Pálavy na katastrech obcí Klentnice a Perná. Cílem studie je prezentace těchto nálezů a jejich zapojení do kontextu osídlení v pálavském mikroregionu. Výsledný obraz nám umožní sledovat strukturu a vývoj osídlení ve starší a střední době bronzové.
\end{abstract}

\section{Klíčová slova}

starší doba bronzová, střední doba bronzová, Morava, Pavlovské vrchy, struktura osídlení

\begin{abstract}
The vicinity of the Pálava hills is renown for its long history of archaeological excavations which ranks it among archeologically best surveyed areas in the country. A recently published list of all the archaeological excavations in the area of the Nové Mlýny dam construction made the data easily accessible. On the contrary the data related to the excavation of the early and middle bronze age sites from the area of the Pálava hills on the Klentnice and Perná cadastre municipalities reamined long unpublished. The aim of this paper is to present these data and bring them into the context of the Pálava microregion settlement. The overall picture can reveal the settlement structure of the area in the early and middle bronze age.
\end{abstract}

\section{Key words}

Early Bronze Age; Middle Bronze Age; Moravia; Pálava hills; settlement pattern; 


\section{1. Úvod}

Starší a střední doba bronzová na Moravě jsou dnes neodmyslitelně spjaty se jménem Stanislava Stuchlíka, který tomuto období věnoval hlavní část své badatelské činnosti. Problematikou moravských únětických sídlišt se zabýval již jako student ve své diplomové a disertační práci (Stuchlik 1972). Konec starší doby bronzové a počátek mohylového období se stal tématem jubilantovy kandidátské disertace (Stuchlik 1979). Společně se svojí ženou Janou, která zasvětila badatelský zájem moravské věteřovské skupině, vytvořili Stuchlíkovi doposud nepřekonaný korpus informací, který tvoří základ každé práce zabývající problematikou starší a střední doby bronzové.

Podobně se Stanislav Stuchlík zapsal do historie archeologického bádání v oblasti Pálavy, když coby editor sestavil publikaci mapující všechny doposud známé lokality v oblasti související s výstavbou vodního díla Nové Mlýny v letech 1975 až 1988 (Stuchlik 2002). Z této oblasti pochází také řada důležitých výzkumů, které Stanislav Stuchlík sám vedl, nebo zpracoval. Jde zejména o výzkum únětického pohřebiště v Mušově - Štěrkovně (Stuchlik 1987) a publikace únětických pohřebišt v Horních Věstonicích (Stuchlik 2006) a v Pavlově - Dolním poli (Stuchlik 1992). Důležitým momentem pro poznání přechodného období mezi starší a střední dobou bronzovou byla publikace věteřovských nálezů odkrytých v roce 1977 v poloze Bulhary - Gajdošova cihelna (Stuchlik 1984).

Cílem tohoto článku je navázat na práci Stanislava Stuchlíka v prostoru Novomlýnských nádrží v horizontu starší a střední doby bronzové a korpus dat rozš́ŕit o nálezy $\mathrm{z}$ katastrů Klentnice a Perné, které doposud nebyly publikovány. Na území těchto katastrů se nacházejí pálavská hradiště známá svými nálezy zejména z období popelnicových polí (Salaš 1987). Zde prováděl v 50. letech četné výzkumy další významný moravský badatel a zároveň jubilantův školitel Jiří Ř́íhovský. Valná část Říhovského výzkumů souvisejících se starší a střední dobou bronzovou byla publikována pouze informativně, nebo vůbec, a proto jim zde bude věnována bližší pozornost. Pro doplnění celkového obrazu struktury osídlení mikroregionu budou do sledované oblasti zařazeny také katastry obcí Bulhary, Mikulov a Sedlec, nebot prostorově s výše jmenovanými katastry souvisejí a na jejich území se nachází početné nálezy ze sledovaného období.

Mikroregion okolí Pavlovských vrchů, nebo také Pálavy se nachází na rozhraní Dyjsko-svrateckého a Dolnomoravského úvalu v místě soutoku Dyje, Svratky a Jihlavy a tvoří přirozený komunikační koridor v ose východ - západ, který je zároveň otevřen i směrem na sever do Brněnské kotliny (obr. 1). Vápencové bradlo Pavlovských vrchů s převýšením až 350 metrů nad okolní krajinu tvoří z dálky viditelný dominantní geomorfologický prvek, jenž přitahoval lidské společnosti nejpozději od mladého paleolitu. Díky bohaté historii amatérských, badatelských i záchranných archeologických aktivit je oblast v okolí Pavlovských vrchů jednou z nejlépe probádaných u nás. Shromážděné informace nám umožňují nahlédnout do sídelní struktury ve starší a střední době bronzové v mikroregionu, který díky své lokalizaci a geomorfologii patřil v pravěku $\mathrm{k}$ významným komunikačním uzlům a k vyhledávaným sídelním komorám. Sledovaná oblast zároveň zahrnuje typově velmi různorodou krajinu a umožní nám sledovat charakter osídlení jak podél páteřního vodního toku, v otevřené krajině s drobnými vodotečemi, tak i v prostoru výrazných geomorfologických útvarů, jakými jsou pálavské kopce. 


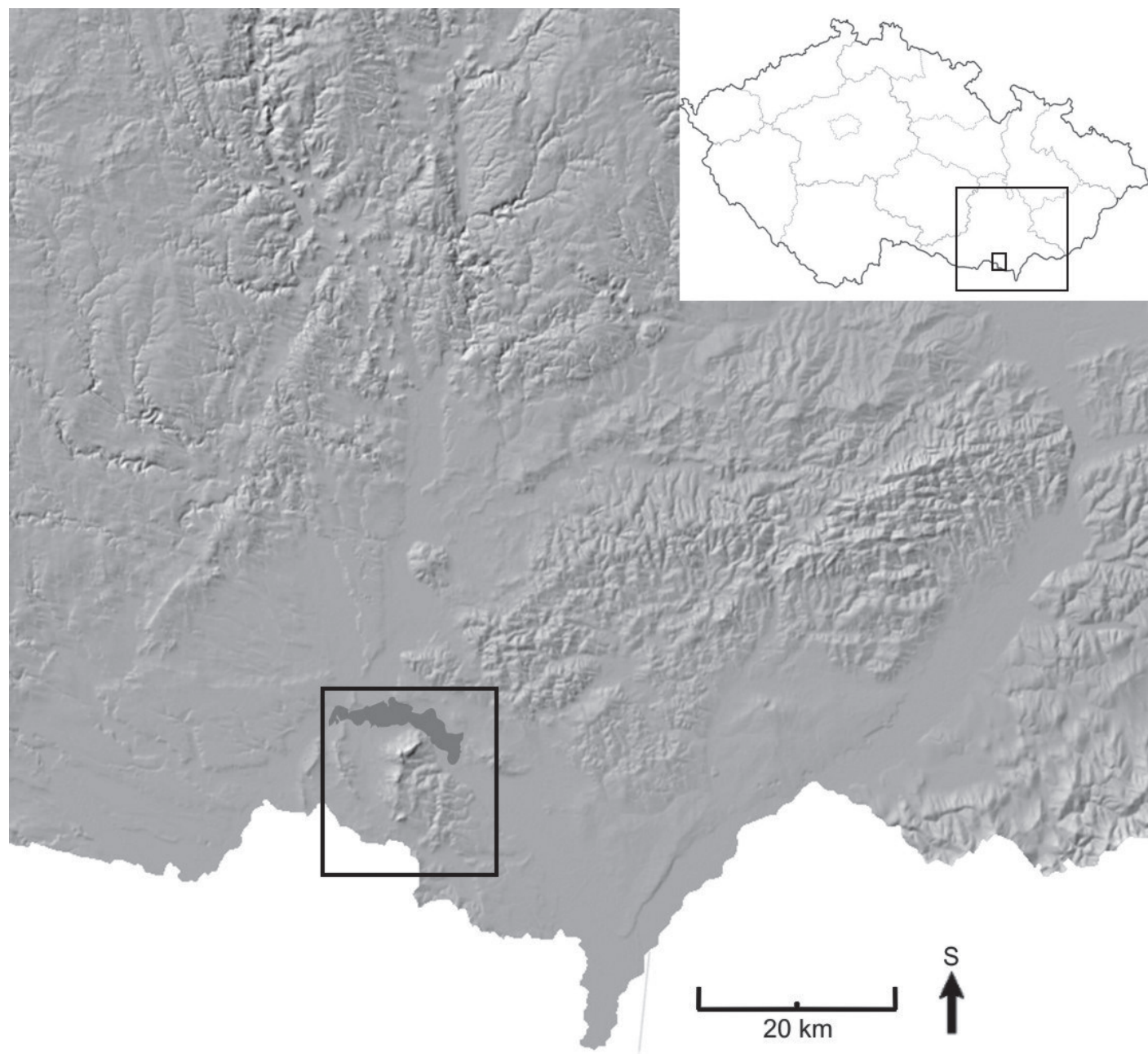

Obr. 1. Vymezení sledovaného mikroregionu na reliéfní mapě jižní Moravy. Tmavou plochou je vyznačen rozsah vodního díla Nové mlýny (zdroj podkladové mapy: ČúZK).

Fig. 1. The area of interest on relief map of South Moravia. Dark area marks the Nové Mlýny dam (map source: ČÚZK). 


\section{Lokality na katastru Klentnice a Perné}

\subsection{Klentnické pohřebiště}

Jednou z nejvýznamnějších lokalit doby bronzové v oblasti Pavlovských vrchů je pohřebiště na severním konci obce Klentnice (obr. 2:1). Nachází se v nadmořské výšce $330 \mathrm{~m}$ v sedle mezi výšinným sídlištěm na Tabulové hoře a sousedním výšinným sídlišstěm v poloze Kotel. Na lokalitě měl počátkem 50. let vzniknout vepř́n, a jelikož byla existence pohřebiště díky četným náhodným nálezům známá, bylo v roce 1952 přistoupeno $\mathrm{k}$ záchrannému výzkumu pod vedením pracovníků Státního archeologického ústavu V. Páleníkové a J. Ǩíhovského. V následujících dvou sezónách v letech 1955 a 1956 byl výzkum rozšířen o další sondy do celkového počtu šesti samostatných ploch (obr. 3). Celková rozloha pohřebiště není známa, je však pravděpodobné, že plochy výzkumy zachytily pouze jeho menší část. Bylo odkryto celkem 124 hrobů $\mathrm{z}$ průběhu celé doby bronzové $\mathrm{a} \mathrm{z}$ doby halštatské. Z nich náleželo 97 žárových hrobů období popelnicových polí, 1 kostrový (hrob 62) a 16 žárových hrobů době halštatské. Všem těmto souborům se dostalo kompletní katalogové publikace (Řihovský 1965a; 1970). Pozornost byla věnována také věteřovskému kostrovému hrobu č. I (Stuchliková 1990, 147). Zbylých 9 kostrových hrobů včetně jejich polohy v rámci pohřebiště zůstalo nepublikovaných. Z těchto devíti hrobů dva (VII, IX) neobsahovaly žádné milodary. Sedm hrobů (II, III, IV, V, VI, X, 90) je na základě nálezů možno datovat do mohylového období. Následující informace včetně obrazového materiálu jsou převzaty $\mathrm{z}$ nálezových zpráv č. 4331/59, 4151/59, 1618/60 uložených na Archeologickém ústavu v Brně. Autorem zpráv je J. Říhovský.

Z prostorového hlediska vytvář́ šest kostrových hrobů (I, III, IV, V, VI, VII) jednu skupi- nu v ploše na východní straně silnice. Hrob II byl zachycen pouze nálezem jehlice a několika drobných zlomků kostí. Nejspíše proto nebyl do plánu vůbec zanesen ani samostatně nakreslen. Zbylé kostrové hroby jsou rozptýleny v sondách na západní straně silnice. Není patrné, že by hroby ze starší a střední doby bronzové vytvářely nějakou výraznou prostorovou tendenci v rámci zkoumaných ploch. Podobně nejsou patrné žádné prostorové tendence ve vztahu k žárovým hrobům z doby popelnicových polí a doby halštatské. Všechny tyto komponenty jsou do značné míry promíchány, nicméně je zároveň zřejmé, že mladší žárové hroby respektují starší kostrové včetně jisté míry prostoru. Lze tedy uvažovat o existenci povrchového označení hrobů, snad v podobě menších mohylových náspů (obr. 3). Hroby byly až na výjimky (IX, X) značně poničené s torzovitě zachovanými skelety (obr. 4). V pěti hrobech byly patrné stopy po zásypu v podobě velkých vápencových kamenů (I, III, IV, 90, IX).

Výbava hrobů je poměrně chudá a sestává povětšinou z jednoho kusu šperku (výjimečně ze dvou v případě hrobu III), případně jednoho až dvou kusů nádob. Chronologicky nejmarkantnější je jehlice s kuželovitou hlavicí a symetrický zduřelým perforovaným krčkem z hrobu č. II (obr. 5:B). Jedná se o typického zástupce staromohylového období, tedy stup-

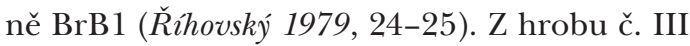
pochází náramek trojúhelníkovitého profilu s pečetítkovitě rozšriřenými konci a páskový prsten s podélnými žebry (obr. 5:C:2). Tento typ náramku s výraznou rytou výzdobou v podobě prríčných rýh a sérií obloučků má těžiště výskytu ve starším a středním mohylovém stupni (Salaš 2005, 78-79). Doprovodný páskový prsten se čtyřmi podélnými žebry přesekávanými rýžkami (obr. 5:C:1) se vyskytuje v průběhu celé střední doby bronzové a nemá zásadnější chronologický význam (Furmánek 1973, 125). Oba šperky se nacházely u jednoho ze 


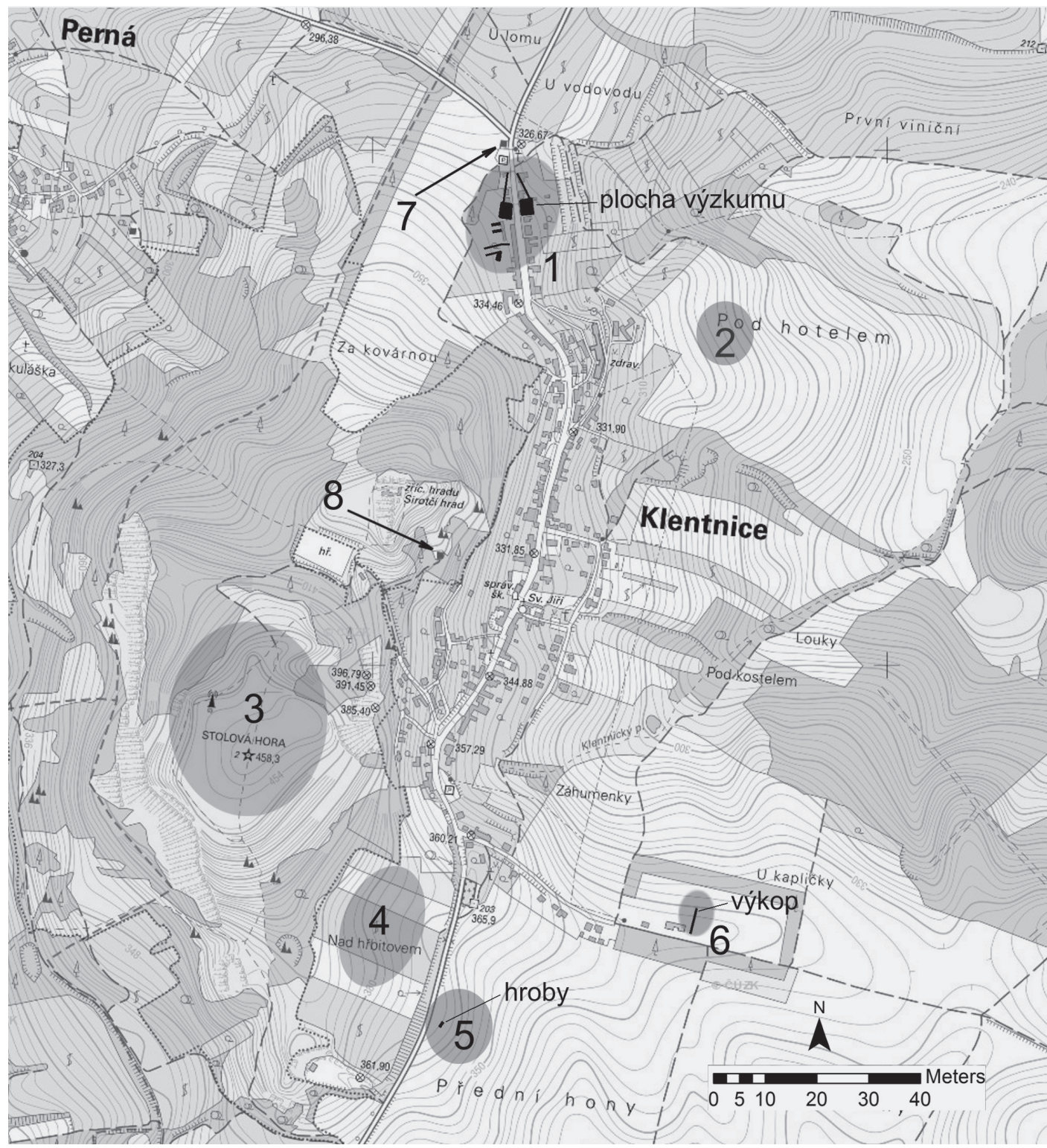

Obr. 2. Lokality na katastru Klentnice. 1: Severní konec obce, 2: Pod hotelem, 3: Tabulová hora, 4: Nad hřbitovem, 5: Přední hony, 6: U kapličky, 7: vodojem na severním konci obce, 8: vodojem „Pod skalou".

Fig. 2. Sites on the Klentnice cadastral municipality. 1: Northern end of the municipality, 3: Tabulová hora, 4: Nad hřbitovem, 5: Přední hony, 6: U kapličky, 7: Northern water tank, 8: Water tank "Pod skalou". 


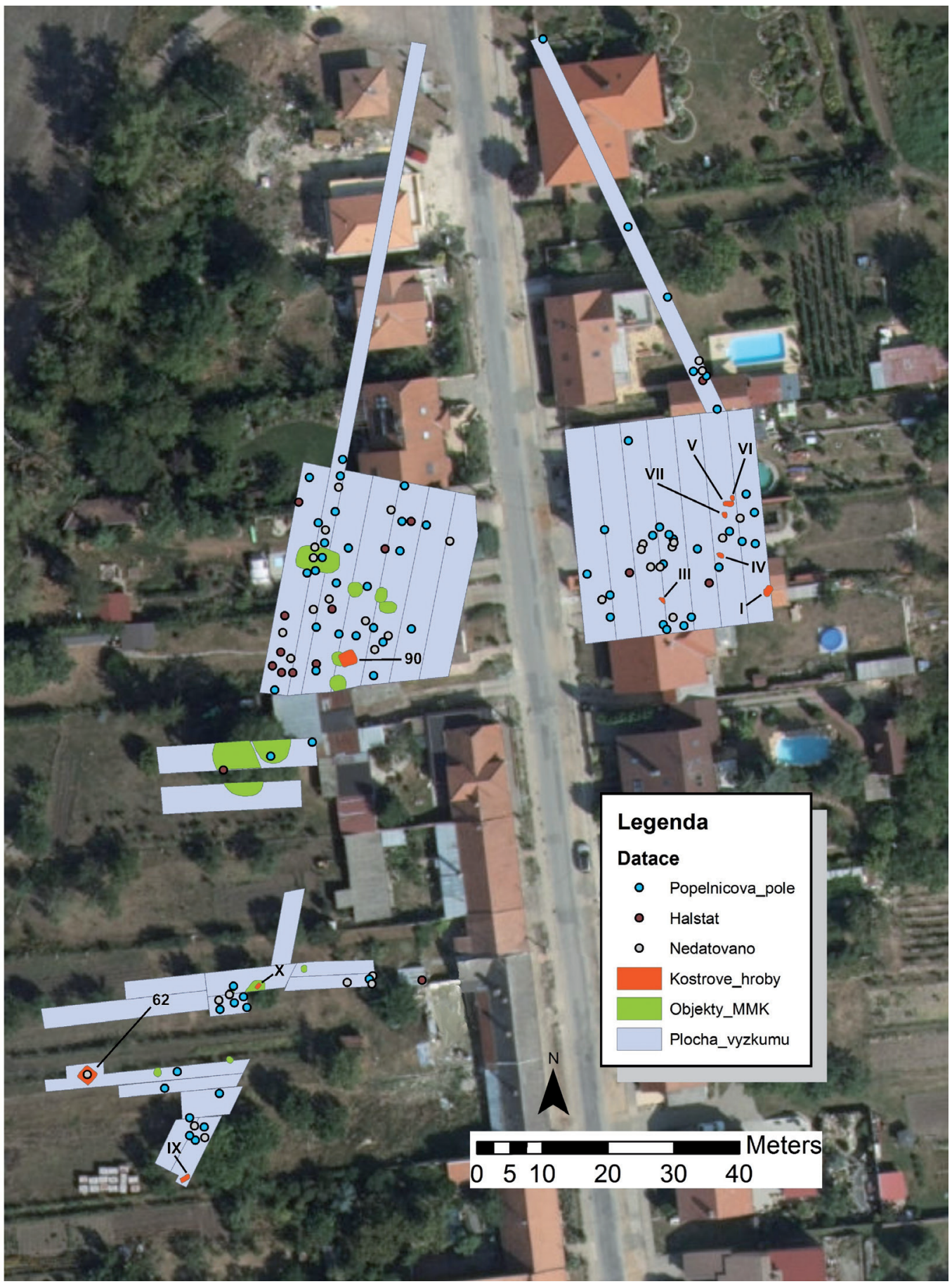

Obr. 3. Digitalizovaný a georeferencovaný plán výzkumu klentnického pohřebiště (podle J. Říhovského). Fig. 3. Georeferenced plan of the Klentnice burial ground excavation (after J. Říhovský). 


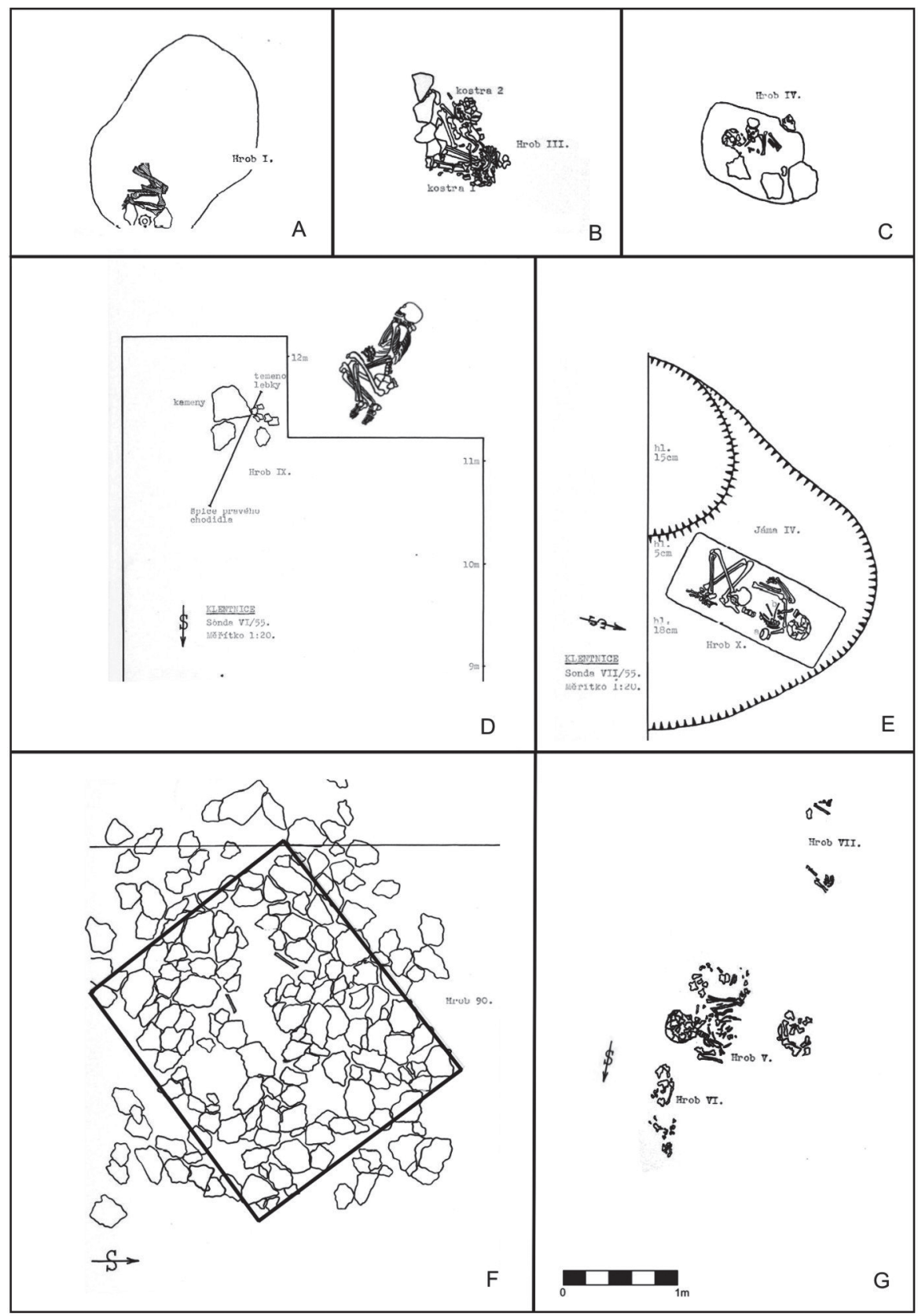

Obr. 4. Situace jednotlivých kostrových hrobů (kresba: J. Říhovský).

Fig. 4. Individual graves (drawing: J. Říhovský). 
dvou jedinců uložených v hrobě. Téměř identická kombinace náramku a prstenu pochází z kostrového dvojhrobu z Mikulova, který byl sérií radiokarbonových dat absolutně datován na přelom 15. a 14 . století př. n. 1., relativně pak do stupně BrB2 respektive BrC1 (ك̌abatová et al. 2020, 222). Hrnky z hrobů č. IV a V (obr. 5:D, E:2) patří ke keramickým tvarům, které bližší datování v rámci mohylového období neumožňují (Stuchlik 2006b, 199). Nepomůže ani jehlice s odlomenou hlavicí v hrobu č. V (obr. 5:E:1). Z hrobu č. VI pochází prostý tenký náramek kruhového profilu se zužujícími se a částečně překrytými konci (obr. 5:F). Tento typ šperku se vyskytuje např́ić celou dobou bronzovou (Salaš 2005, 90) a do mohylového kontextu tak hrob řadí především prostorová vazba na hrob č. V, jejichž vzájemná blízkost naznačuje, že snad mohlo jít o dvojhrob (obr. 4:G). Za zmínku stojí vysoká koncentrace tohoto typu náramků ve věteřovských hrobech borotického mohylníku (Stuchlik 2006b, 179). Známe je však např́klad i z kontextu pozdněbronzového pohřbu v Ivanovicích na Hané (Parma et. al. 2018, Fig. 5).

Ačkoliv amfory s vertikálními uchy se s velkou variabilitou vyskytují v průběhu celé střední doby bronzové (Stuchlik 2006b, 194), exemplář s vypíchanou výzdobou obilného zrna pod rozhraní hrdla a těla a s plastickými výčnělky na spodní výduti z hrobu č. X (obr. 5:G) se hlásí spíše k mladším tvarům, jako je například

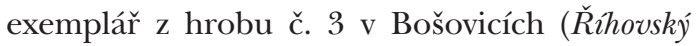
1982, 20, tab. 20: B, 10). Chybí však svislé žlábkování typické pro pozdní vývoj. Blíže časově nezařaditelné je torzo stejného typu amfory z hrobu č. 90, podobně jako doprovodný šálek s prohnutým hrdlem, jehož nevýrazný přechod k výduti je zvýrazněn horizontální linií vpichů v podobě obilného zrna (obr. 5:H). Tvar i výzdoba se vyskytují po celou střední dobu bronzovou a nepředstavují chronologicky citlivější prvek (Stuchlik 2006b, 193, 203).
S pohřebištěm souvisí celá řada jednotlivých nálezů ze zahrad okolních domů (obr. 5:I). Početné nálezy z narušovaných hrobů ostatně plnily sbírku v knihovně Mikulovského zámku již od počátku 19. století a od roku 1922 pak i nově vzniklé „Heimatsmuseum in Klentnitz“ (Koch 1853, 27; Schirmeisen 1938, 70). Tyto sbírky však byly z valné části rozchváceny během dramatických událostí roku 1945. V. Furmánek datuje nálezy z klentnického pohřebiště do stupňů BrB2-C1 (Furmánek 1973, 130). Vychází však pouze z ojedinělých nálezů, zatímco materiál ze systematického výzkumu zůstal opomenut. Z nálezu jehlice z hrobu č. II plyne, že je třeba počítat s existencí pohřebiště již ve stupni BrB1. Amfora z hrobu č. X naznačuje možnost pohřbívání i v mladším období. Zdá se tedy pravděpodobné, že na klentnickém pohřebišti můžeme sledovat kontinuální vývoj pohřbívání od věteřovského období po celou střední dobu bronzovou.

\subsection{Další pohřební areály z katastru Klentnice a Perné}

Ze starší doby bronzové byl zachycen další potencionální pohřební areál v trati Klentnice - Pod hotelem (obr. 2:2). V roce 1957 zde byl podle nálezové zprávy J. Ondráčka (nálezová zpráva Archeologického ústavu Brno č. 327/58) narušen orbou únětický hrob, z nějž se zachovala porušená lidská lebka a několik únětických střepů. Nálezy se bohužel nepodařilo dohledat. Z lakonické zprávy vyplývá, že zde v předchozích letech bylo narušeno podobných situací více a jedná se tedy o pohřebiště. Sondy v okolí nálezu nicméně žádné další objevy nepřinesly.

Mimo pohřebiště na severním konci obce se na katastru Klentnice nacházejí minimálně ještě dva pohřební areály z mohylového období. Prvním z nich je pohřebiště v trati U kapličky 


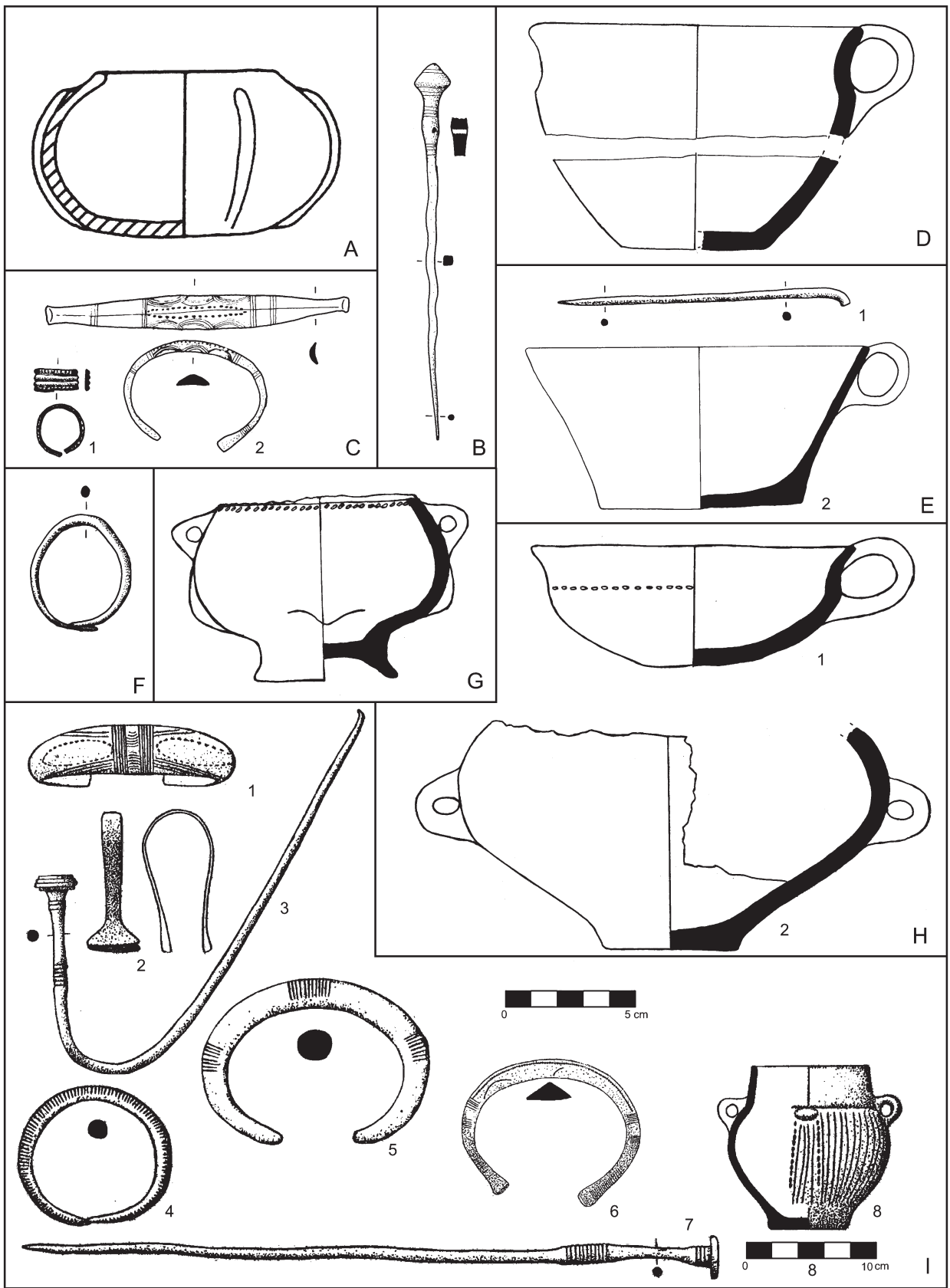

Obr. 5. Inventáŕ kostrových hrobů z klentnického pohřebiště. A: č. I, B: č. II, C: č. III, D: č. IV, E: č. V, F: č. VI, G: Č. 90, H: č. IX, I: náhodné nálezy. (A: podle Stuchlík 1993, I: podle Stuchlík 1979).

Fig. 5. Inventory of the Klentnice graves. A: no. I, B: no. II, C: no. III, D: no. IV, E: no. V, F: no. VI, G: no. 90, H: no. IX, I: single finds. (A: after Stuchlík 1993, I: after Stuchlík 1979). 
(nebo také Záhumenky) ca $500 \mathrm{~m}$ východně od hřbitova v prostoru bývalého JZD (obr. 2:6). Druhým je trat’ Přední hony ležící jižně od hřbitova ve vzdálenosti ca $260 \mathrm{~m}$ (obr. 2:5). Kovový materiál z těchto lokalit byl publikován V. Furmánkem (Furmánek 1972, 66-67) a spolu s keramickými nálezy se objevil také v disertaci S. Stuchlíka (Stuchlik 1979, tab. 51-53).

V trati U kapličky došlo při budování kanalizace pro JZD v roce 1958 k nálezu lidské kostry a bronzového nože (obr. 6:A-C ). Výkopové práce narušily situace s celkem 5 lidskými skelety. Prozkoumané hroby tvořily dvě skupiny. První sestávala z pohřbů č. 1-3 a pravděpodobně se jednalo o dvě hrobové jámy v superpozici. Druhá skupina sestávala ze dvou samostatných hrobů ležících přibližně $12 \mathrm{~m}$ jižně od první skupiny. Oba hroby byly narušené a bez milodarů a v obou př́padech je patrný kamenný zával (nálezová zpráva Archeologického ústavu v Brně č. 1053/59). J. Ř́hovský datuje hroby v trati U kapličky na základě nože do mladšího mohylového stupně (Řihovský 1972, 41), zatímco V. Furmánek se přiklání k dataci souboru do stupně BrB2 (Furmánek 1973, 129).

V trati Přední hony byly v roce 1957 orbou narušeny dva kostrové hroby. Výzkumem byla zjištěna téměř kompletně zachovalá kostra prvního jedince ve skrčené poloze a narušená kostra druhého (obr. 7:A-B ). Jedinci byli uloženi hlavami proti sobě. $\mathrm{V}$ prostoru mezi pohřby ležela artikulovaná část zadní končetiny blí̌ze nespecifikovaného zvírete. U nohou prvního pohřbu se našly dva drobné střepy z hrncovitých nádob (nálezová zpráva Archeologického ústavu v Brně č. 773/60). Ačkoliv nejde o př́liš dobře časově zařaditelnou keramiku, dataci lokality potvrzují kovové nálezy z detektorové prospekce z let 2008-2019, které mohou odpovídat situaci narušeného pohřebiště $\mathrm{z}$ mohylového období. Jde konkrétně o náramek kruhového profilu se zúženými konci zdobený čtyřmi svazky příčných rýh (obr. 7:C:4). Tento typ náram- ků je typický pro střední dobu bronzovou, nicméně může přežívat i do období popelnicových polí (Salaš 2005, 90-91). Podobný náramek pochází např́klad z dvojhrobu z Mikulova ( $\check{S} a-$ batová et. al. 2020, orb. 12, 2). Dalším nálezem je zlomek náramku plochého bikonvexního až oválného profilu, jehož dochované zakončení je vyzdobeno dvěma příčnými žebírky a zploštělou kuličkou. (obr. 7:C:1). Typologicky jde o ojedinělé provedení, které nicméně vykazuje jistou př́buznost $\mathrm{s}$ plochými náramky s podélnými žebry. Žebra na klentnickém exempláři provedena nejsou, nicméně podélné členění je naznačeno rytím. Nízká míra zahnutí náramku naznačuje nedokončený výrobní proces, nebot ploché náramky byly ohýbány až dodatečně po odlití. Podobně nedokončený je zachovaný plochý náramek v depotu z obce Krupá ve středních Čechách (Kytlicová 2007, 41, 270, Taf. 9C). Tento typ plochých náramků s podélnými žebry se vyskytuje od mladšího mohylového období až do doby starších a středních popelnicových polí (Kytlicová 2007, 41; Salaš 2005, 94-95), s naším exemplářem jej však můžeme spojovat pouze nepřímo.

Existenci dalšího možného pohřebního areálu naznačuje nález hrobu v trati nazvané podle nálezové zprávy Archeologického ústavu Brno č. 796/49 „Pod Skalou (Růžový hrad)“ (obr. 2:8). Zde byl v roce 1948 při výkopu pro vodojem v hloubce $60 \mathrm{~cm}$ rozrušen kostrový hrob $\mathrm{s}$ jehlicí, náramkem a keramickou amforou (obr. 6:D). Přesná lokalizace nálezu je však problematická. Pokud se jedná o vodojem, který se nachází v poměrně příkrém skalnatém svahu pod Sirotčím hrádkem (dříve nazývaného Rosenberg/ Růžový hrad), čemuž odpovídá název trati, jde o velmi neobvyklé místo pro pohřební areál. Druhý obecní vodojem se přitom nachází jen několik desítek metrů severně od klentnického pohřebiště a mohlo by se tak jednat o další z mohylových hrobů v jeho areálu (obr. 2:7). Znamenalo by to však, že došlo k záměně 


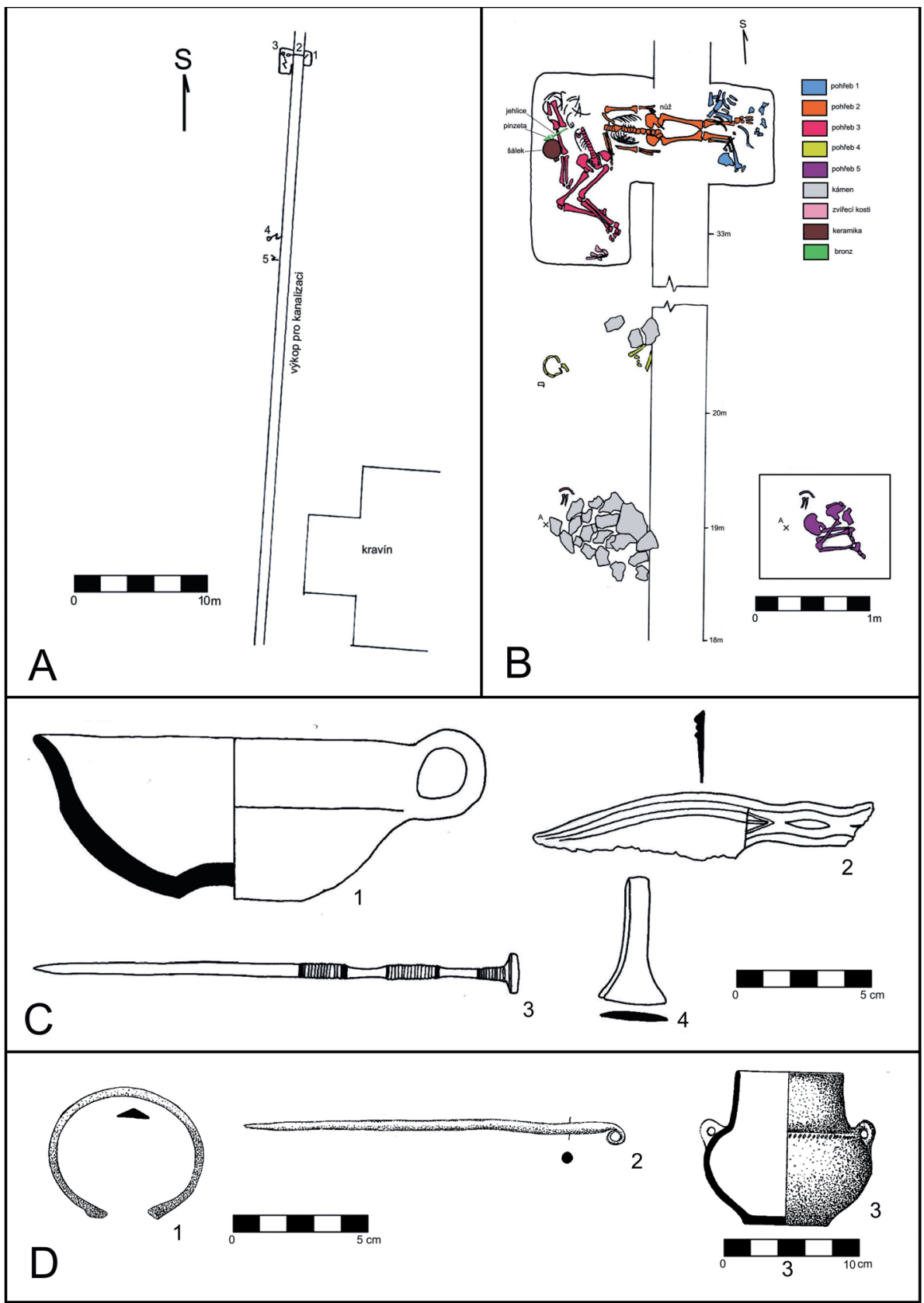

Obr. 6. A-B: nálezová situace v trati Klentnice - U kapličky (podle J. Říhovského, upraveno), C: výbava hrobů v trati Klentnice - U kapličky, D: výbava hrobu „Pod skalou” (podle Stuchlík 1979).

Fig. 6. A-B: a documentation of the graves from the Klentnice - $U$ kapličky site (after J. Říhovský, edited), C: inventory of the graves from the Klentnice - $U$ kapličky site, D: inventory of the grave from the "Pod skalkou" site (after Stuchlík 1979). 


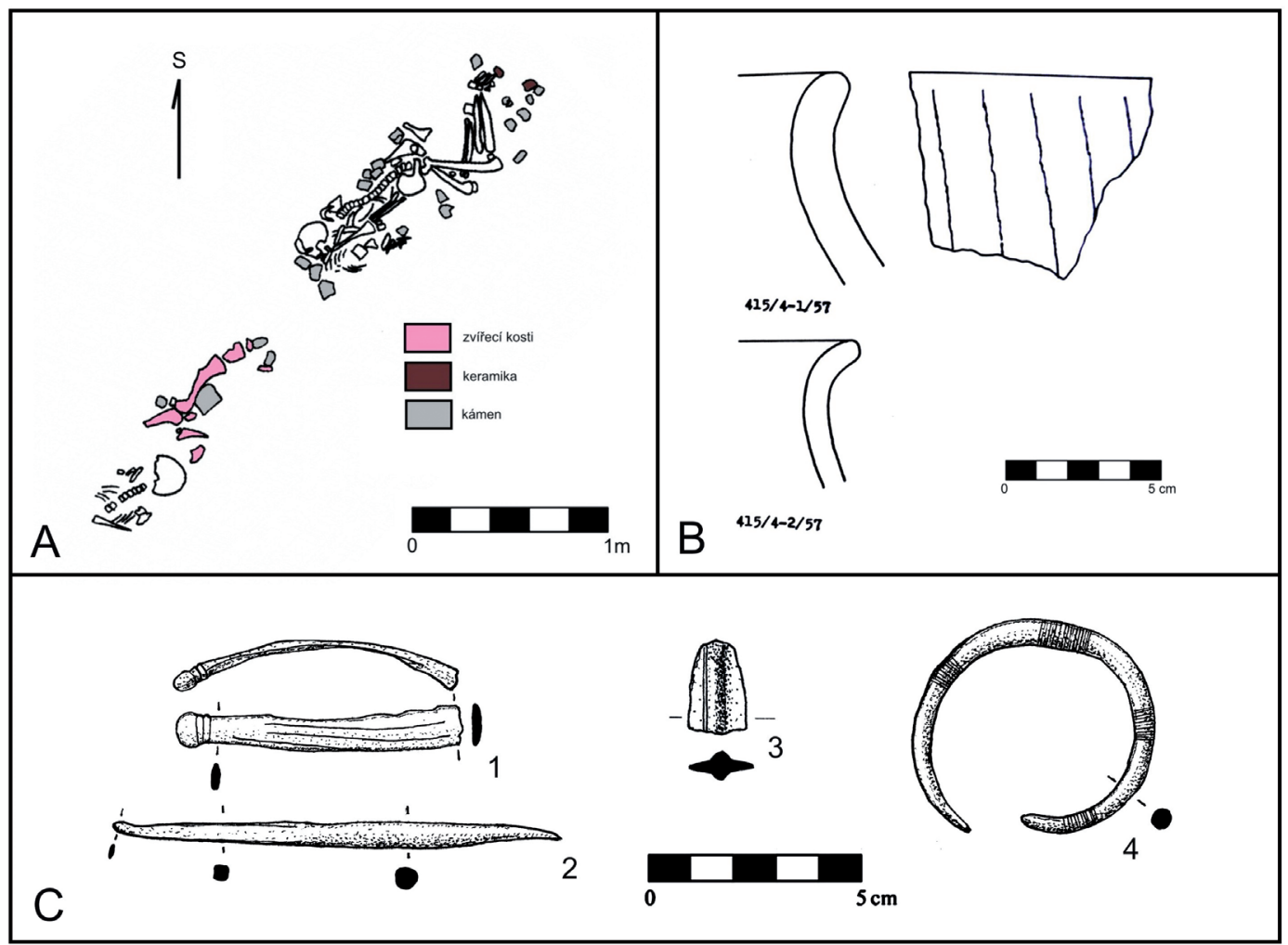

Obr. 7. A-B: nálezová situace $v$ trati Klentnice - Přední hony (podle J. Říhovského), C: ojedinělé nálezy z trati Klentnice - Přední hony.

Fig. 7. A-B: documentation of the graves from the Klentnice - Přední hony site (after J. Říhovský), C: single finds form the Klentnice - Přední hony site.

lokalit při sepisování nálezové zprávy. Tato varianta není úplně vyloučena, nebot rok nálezu a vyhotovení zprávy od sebe dělí jeden rok. Výbava hrobu neumožňuje $\mathrm{v}$ rámci mohylového období bližší chronologické zařazení.

\subsection{Sídelní areály na katastru Klentnice a Perné.}

Ze sídelních areálů na katastru Klentnice je nejmarkantnější hradiště na Tabulové hoře (obr. 2:3). Ojedinělé keramické nálezy dokládají využívání lokality již v období eneolitu. Lokalita byla zjevně využívána i ve starší době bronzové, z dostupných informací však není možné určit jednoznačný charakter těchto aktivit. Doklady o ohrazení areálu ve starší době bronzové chybí. Extenzivní doklady osídlení včetně valového ohrazení pocházejí až z období popelnicových polí (Ľíhouský 1955; Navrátil - Bíško - Tencer 2020). V keramickém materiálu získaném během výzkumu J. Ř́hovským v 50. letech jsou starobronzové střepy zastoupeny pouze $4 \%$ (12 zlomků) z celkového počtu reprezentativních keramických jedinců (obr. 8:A:1-12) a jedná se pouze o velmi nevýrazný materiál zařaditelný do únětického stylu. Kovovými předměty je za- 
stoupena jedna jehlice s kulovitou, šikmo protknutou hlavicí (obr. 8:A-13). Tento typ jehlice je na Moravě spojován s věteřovským obdobím, nicméně řadu exemplářů známe i z únětických hrobů (Benkovsky-Pivovarová 2005; Stuchlik 1987, 64, obr. 32:5; Ondráček 1962, 76; Novotná 1980, 45-46). Bohužel zpětně neověřitelné jsou další starobronzové nálezy údajně pocházející z Tabulové hory - masivní terčovitá jehlice ( $\mathrm{Na}$ vrátil 2010, 101, obr. 107) a dva soubory zlatých vlasových ozdob (Stuchlik 2018), které pocházejí z nelegální detektorové činnosti a informace o nich je tak třeba považovat za kompromitované.

O využívání Tabulové hory v mohylovém období napovídá zatím pouze detektorový nález dýky s obloukovým týlem (obr. 8:A:16; Navrátil - Biško - Tencer 2020, 80) a informace J. Říhovského, podle které byla během výzkumu v tělese první fáze valu objevena ,pinzeta mohylového charakteru“. Na základě tohoto nálezu datoval J. Ř́ihovský nejstarší fázi opevnění do závěru mohylového období (Ř́ihovský 1955, 31). Pinzetu se bohužel nepodařilo dohledat. Z keramického materiálu mohou spadat do mohylového období dva zlomky výduti s tzv. „vypnulinami“, (obr. 8:A:14-15; Stuchlik 2006, 204).

Další sídelní areál na klentnickém katastru se nachází v poloze Nad hřbitovem u jihovýchodní paty Tabulové hory (obr. 2:4). Lokalitu zachytil na svých mapkách již J. Ř́hovský v souvislosti s průzkumem zázemí hradiště v době popelnicových polí, ačkoliv adresně se o lokalitě nikdy nezmínil (̌̌íhouský 1957, obr. 60; 1965b, obr. 6). Díky dlouhodobé prospekční činnosti dnes máme z lokality k dispozici materiál, který dokládá její využití v závěru starší i ve střední době bronzové. Nález ze závěru starší doby bronzové představuje zlomek tzv. chlebového idolu (obr. 9:A:4). Střední dobu bronzovou reprezentují typické zlomky keramiky, jako jsou výdutě amfor s vypnulinami, nebo vypíchanou výzdobou tzv. obilného zrna na rozhraní hrdla a výdutě (obr. 9:A:5-6; Stuchlik 2006, 203-205). Z kovových nálezů je to pak terčovitý závěsek a zlomek náramku trojúhelníkovitého profilu (obr. 9:A:7-8). Zatímco trojúhelníkovitý profil je typický pro náramky střední doby bronzové s přežíváním do staršího období popelnicových polí (Salaš 2005, 78), těžištěm výskytu terčovitých závěsků je stupeň BrB (Stuchlik 1979, 99102; Wells-Weyrauch 1978, 39-41).

Na katastru Perné byl zjištěn sídelní areál z věteřovského období v trati Pod lomem (obr. 10:52), kde bylo během záchranného výzkumu odkryto 20 věteřovských objektů (Rakovský - Peška - Vitula 1991). Výzkum bohužel nebyl doposud zpracován. Jednotlivé doklady aktivit ze starší i střední doby bronzové pocházejí také z výšinné lokality na Kotli (obr. 10:53). Nálezy z této polohy jsou výhradně výsledkem detektorových prospekcí. Starší doba bronzová je zastoupena nálezem týlové části sekery s lištami (obr. 9:B:2) a jehlice s kulovitou, šikmo protknutou hlavicí (obr. 9:B:5). Dalším zástupcem je zlomek keramiky, který velmi pravděpodobně pochází z věteřovského koflíku (obr. 9:B:1) - jde o typický přechod hrdla a dna s plastickým výčnělkem a omfalem, jaké známe například u exemplářů z Hodonic, nebo Lovčiček (Stuchlíková 1988, obr. 3:7; Stuchliková 1999, obr. 3:11). Střední doba bronzová je zastoupena zlomkem ucha ze džbánku (obr. 9:B:4) a jedinečným zlomkem oboustranné odlévací pískovcové formy (obr. 9:B:3). Zatímco z jedné strany byl do formy odléván blíže nespecifikovaný drobný předmět, druhá strana byla určena pro odlévání již výše zmíněných terčovitých závěsků, jejichž těžiště výskytu je ve starším a středním mohylovém stupni.

Mezi starší a blíže nelokalizované nálezy z klentnického katastru, které taktéž dokládajî starobronzové a mohylové aktivity, patří několik seker s lištami a se schůdkem, které již popsal J. Říhovský (1992, Nr. 168, 178, 214, 307, 312, 389, 395; obr. 8:B) 


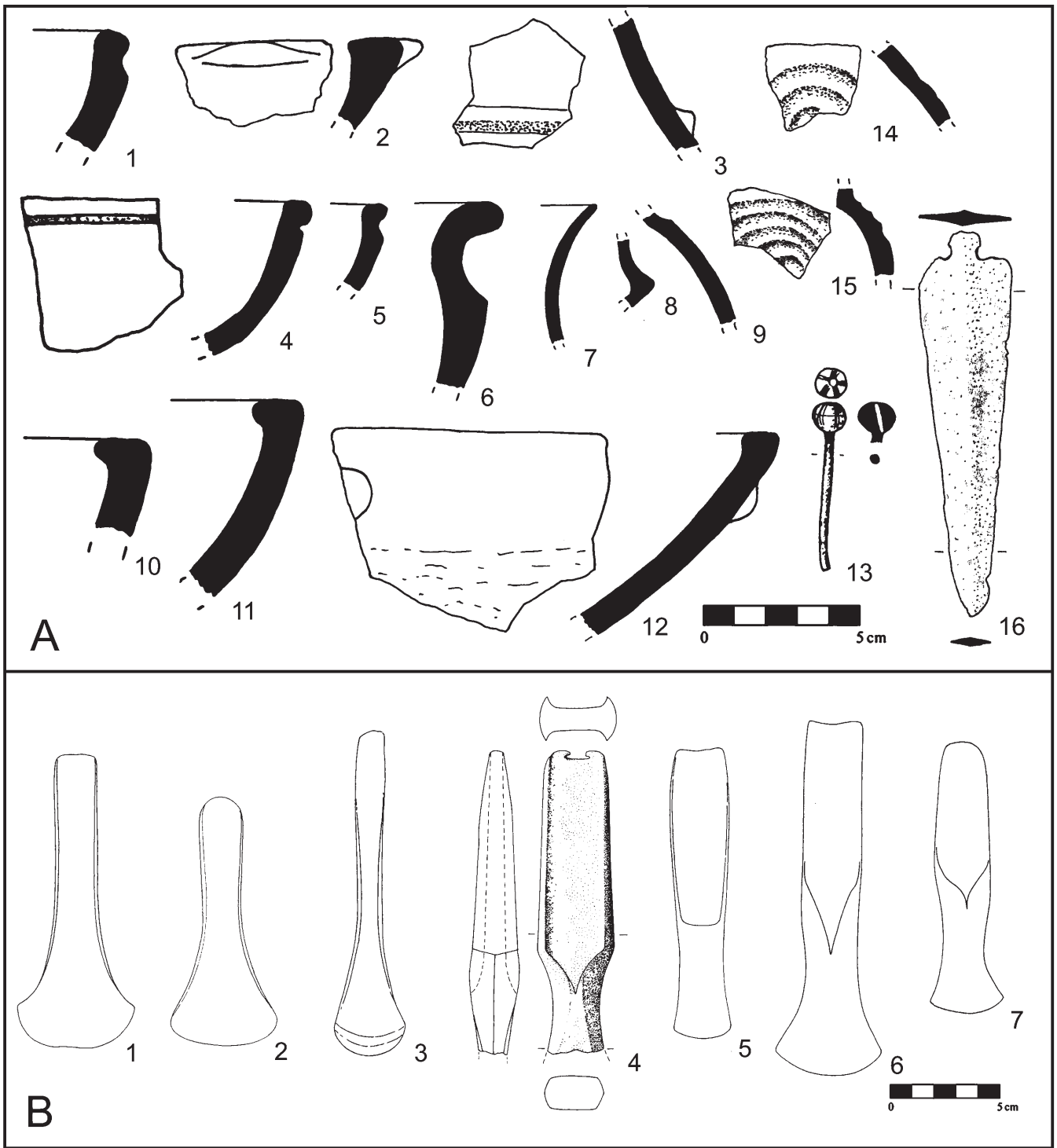

Obr. 8. A: Keramické a kovové nálezy ze starší a střední doby bronzové z trati Klentnice - Tabulová hora, B: blí̌e nelokalizované ojedinělé nálezy seker se starší a střední doby bronzové z klentnického katastru (podle Říhovský 1992).

Fig. 8. A: pottery and metal finds from the early and middle bronze age found on the Klentnice - Tabulová hory site, B: non-located single finds of early and middle bronze age axes found on Klentnice cadastre municipality. 


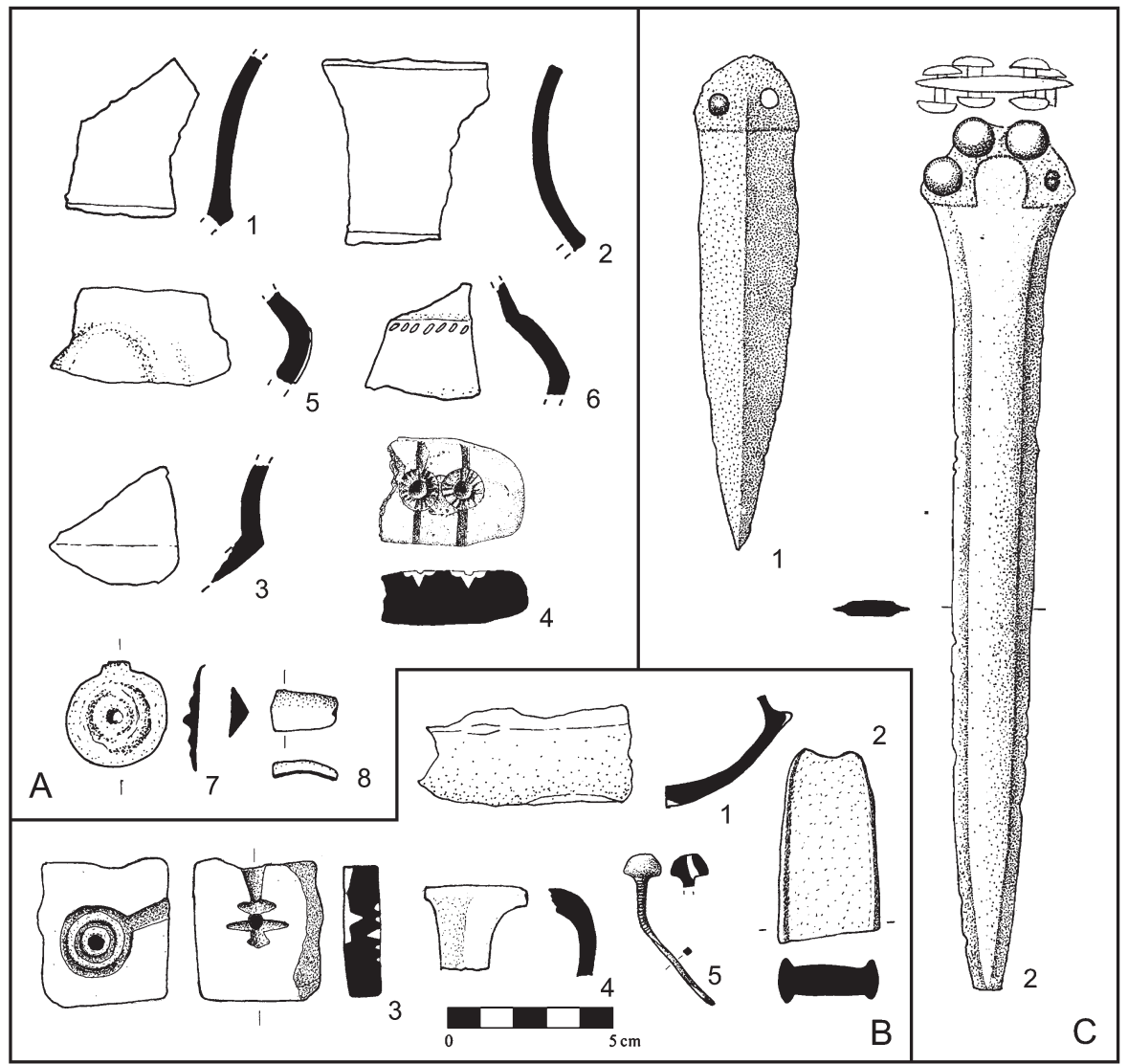

Obr. 9. A: nálezy z povrchových sběrů v trati Klentnice - Nad hřbitovem, B: ojedinělé nálezy z trati Perná - Kotel, C: ojedinělé nelokalizované nálezy z kletnického katastru (podle Stuchlík 1979).

Fig. 9. A: survey finds from Klentnice - Nad hřbitovem, B: single finds form Perná - Kotel site, C: single non-located finds from Klentnice cadastre municipality (after Stuchlík 1979).

\section{Osídlení pálavského mikroregionu}

Díky vysoké míře probádanosti pálavského mikroregionu se nabízí jedinečná možnost zkombinovat výše popsané informace s daty nashromážděnými $\mathrm{S}$. Stuchlíkem v oblasti vodního díla Nové Mlýny. Pokud tato data aktualizujeme o nové nálezy a doplníme dostupné informace z katastru Mikulova, Sedlece a Bulhar, získáme poměrně podrobnou představu o sídelní struktuře ve starší a střední době bronzové v prosto- ru pomyslného mapového listu o délce strany $15 \mathrm{~km}$. Navzdory těmto z archeologického hlediska velice př́íznivým podmínkám je však třeba stále míti na paměti přirozenou torzovitost výčtu archeologických lokalit ve sledovaném prostoru. Tu naznačuje například skutečnost, že průběžné stavební práce související s výstavbou turistické a zábavní infrastruktury na katastru bývalého Mušova a Pasohlávek v posledních letech odhalují stále další a další archeologické lokality (Komoróczy - Klanicová - Navrátil - 


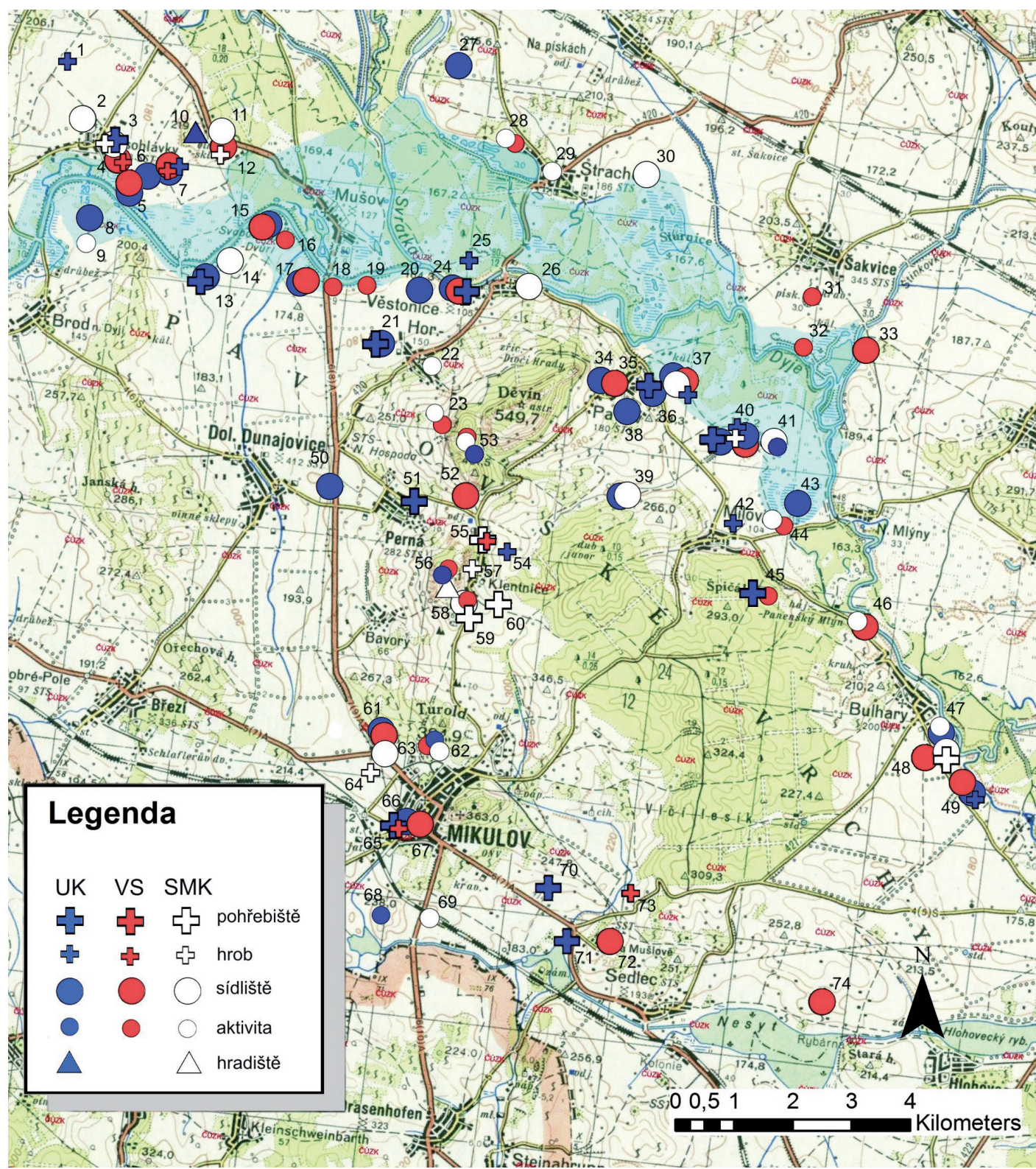

Obr. 10. Lokality s komponentami ze starší a střední doby bronzové ve sledovaném mikroregionu na mapě z roku 1952 zachycující oblast před výstavbou vodního díla Nové Mlýny (zdroj podkladové mapy: ČúZK).

Fig. 10. Sites with the early and middle bronze age components in the area of interest presented on a 1952 map preceding the building of the Nové Mlýny dam (map source: ČÚZK) 
Sázelová - Vlach 2010; Cibulka 2015, informace D. Cibulky). Nové nálezy pocházejí také z katastru Mikulova (Šabatová et al. 2020; Trampota 2012; Piačková 2012) a v neposlední řadě z prostoru Pavlovských vrchů díky dlouhodobému nedestruktivnímu průzkumu prováděném Regionálním muzeem v Mikulově a Muzeem města Brna (Navrátil - Biškko - Tencer 2020; Holubová - Navrátil 2020; Goláñová - Navrátil 2017).

\subsection{Kvantitativní zastoupení komponent}

Ve sledovaném prostoru bylo doposud zjištěno 74 archeologických lokalit ze starší a střední doby bronzové, na nichž se vyskytlo celkem 113 komponent. Komponenty jsou rozděleny chronologicky na tři časové úseky (únětická, věteřovská, mohylová) a typově na sídelní (sídliště $\mathrm{s}$ doloženými objekty, hradiště s doloženým ohrazením/př́ikopem), pohřební (pohřebiště, jednotlivé hroby) a nespecifikované/jiné (ojedinělé nebo hromadné nálezy). Z kvantitativního hlediska je nejpočetněji zastoupena sídelní komponenta únětická (22 lokalit) následovaná jen o něco méně početnými sídelními areály věteřovskými (19 lokalit). Výrazně méně početná jsou sídliště mohylového období (14 lokalit). Známým jevem je kontrast mezi počtem únětických a věteřovských pohřebních areálů na Moravě (Stuchliková 1990). Tento jev je dobře patrný i v námi vytýčeném prostoru. Zatímco únětických pohřebních komponent bylo doloženo 19 , věteřovských pouze 5 přičemž ve dvou případech se jedná o jednotlivé hroby (Klentnice - Severní konec obce, Pasohlávky - Za Tuchnou) a ve třech o pohřby v pithu (Pasohlávky - U vodárny, Mikulov - Kowalského pískovna, Mikulov - Pod Velkým rohem). Pohřebních areálů z mohylového období bylo doposud doloženo 10. Zvláštní v tomto kontextu je poměr komponent, které sestávají z náhodných nebo detektorových nálezů či blíže nespecifikovatel- ných archeologických situací. Zde je únětická komponenta zastoupena pouze $v$ pěti př́ípadech, zatímco věteřovská ve dvanácti a mohylová v deseti.

Zobrazení dat ve sloupcovém grafu umožňuje sledovat vzájemné rozdíly v kvantitativním zastoupení jednotlivých komponent (obr. 11:A). Ačkoliv výsledek ukazuje početnější výskyt únětických sídlišt vưči věteřovským, rozdíl je téměř zanedbatelný. Pokud k sídelním komponentám připočítáme také osamocené nálezy bez kontextů, počet věteřovských lokalit by byl dokonce vyšší. Výsledný obraz se tak liší od podobných v minulosti zveřejněných analýz, které srovnávaly počet únětických a věteřovských komponent. Ty byly založeny na datech pocházejících z činnosti Ústavu archeologické památkové péče Brno (dále ÚAPP), detailněji pak právě z oblasti vodního díla Nové Mlýny (Parma 2015, obr. 1; Šabatová - Parma 2019, obr. 1) a z okresu Břeclav (Peška 1992, 50). V těchto studiích vždy výrazně převažuje únětická komponenta nad věteřovskou, což dobře zapadá do tradiční koncepce chronologického vývoje starší doby bronzové. Podle ní únětická kultura spadá do Reineckeho stupňů BrA1 a části BrA2 (ca 300 let), zatímco věteřovské osídlení mělo zabírat pouze samotný závěr stupně BrA2, respektive úplný počátek stupně BrB1 (ca 100 let - Stuchlik 1984; Stuchlik 1993, 240; Stuchliková 1993, 265). Jak tento rozdílný výsledek, který vznikl z části na stejných datech vysvětlit? Do určité míry je rozdíl způsoben faktem, že ve výše zmíněných pracích byla do kvantitativního srovnávání zahrnuta nejen sídelní, ale i pohřební komponenta. Jak již bylo zmíněno, věteřovský styl je na Moravě spojen s výraznou absencí pohřebních areálů. Ačkoliv již v dnešní době známe celou řadu věteřovských hrobů (Stuchlik 2006, 137-144; Šabatová - Parma 2019, 7-8), rozdíl ve srovnání s počtem únětických pohřebišt je stále dramatický. U věteřovských lokalit nám tak optikou archeologických pramenů chybí téměř celá 
jedna komponenta, což však odráží proměnu v ideologické sféře společností, nikoliv pokles nebo kratší trvání sídleních aktivit. V námi sledovaném prostoru je potenciál takového zkreslení obzvláště dobře patrný a nejspíše i vysvětluje nekonsistenci ve starší a novější interpretaci dat z oblasti Novomlýnských nádrží. Nevysvětluje však diskrepanci vůči datům pocházejícím z výzkumů ÚAPP v oblasti celé jižní Moravy.

Jedním z možných vysvětlení vysokého zastoupení věteřovské komponenty $\mathrm{v}$ oblasti Pálavy v porovnání s daty pocházejícími z výzkumů ÚAPP na jižní Moravě může být jistá specifičnost pálavského mikroregionu. Jak již bylo zmíněno v úvodu, celá oblast představovala v pravěku významný komunikační uzel a díky jedinečné geomorfologii také výrazný bod v sociální krajině. Tato skutečnost mohla mít zásadní vliv na intenzitu osídlení v určitých etapách pravěku. Oblast tak může představovat atypický vzorek.

Dalším důvodem může být způsob sběru dat, nebot velká část archeologických informací v pálavském mikroregionu pochází ze záchranných akcí souvisejících s výstavbou vodního díla Nové Mlýny, což z hlediska moravské archeologie byla a doposud je akce bezprecedentního rozsahu. 13 let záchranných archeologických výzkumů umožnilo poměrně solidní poznání rozsáhlé části krajiny, která navíc v pravěku patřila k jedné z nejhustěji osídlených sídelních komor. V kombinaci s bohatou historií archeologických výzkumů celé oblasti tak může sledovaný mikroregion nabízet kompaktnější „archeologickou mapu“, než jakou nabízí mapa založená na datech pocházejících z investorských a prostorově jen málo propojených záchranných akcí. Pravděpodobně jde o kombinaci obou výše popsaných faktorů.

Pokud se podíváme na problém optikou absolutní chronologie, není vysoké zastoupení a tedy i potencionálně delší trvání věteřovské komponenty na pomyslné časové ose natolik anomálním jevem. Podle sumarizace aktuálních radiokarbonových dat pocházejících z moravských kontextů vykazuje věteřovská komponenta velmi široký časový rozptyl ležící mezi daty 1900-1500 BC (Peška 2012, Peška 2019, 105-105, Abb. 5). Podobnou situaci vykazují i některá data z mad’arovských lokalit na Slovensku (Navrátil 2017, 36-37, obr. 2.16). Je zjevné, že s rostoucím počtem radiokarbonových dat roste také potenciál konfliktu absolutní chronologie s tradičním pojetím typologického vývoje archeologických kultur. Hlavní problémy vyvstávají v oblasti jejich vnitřního členění, kde data ne vždy zapadají do zaběhlých typochronologických schémat u konkrétních typů předmětů, a dále v oblasti přechodu mezi následnými archeologickými kulturami, kde sumarizovaná data často ukazují na překryv jejich existence (Benkovsky-Pivovarová 2001, 224; Peška 2019, 106, 108; Müller 1999, 71; Stockenhammer et al. 2015; Massy - Stockhammer 2019; srov. Kuг̌a et al. 2012; Trampota - Květina 2020). V tuto chvíli zatím stále není jasné, do jaké míry je problém v metodě sběru a interpretace radiokarbonových dat (Peška 2019, 97-98) a nakolik v tradičním pojetí typochronologického a kulturně-historického schématu (Navrátil 2017, 41-43).

Výrazně nižší kvantitativní zastoupení mohylové sídelní komponenty vưči únětické a věteřovské je $s$ největší pravděpodobností odrazem dobře zdokumentovaného trendu ve změně sídlištní struktury s nástupem střední doby bronzové. Mohylová komponenta se na sídlištích projevuje oproti předchozímu období výrazně nižším počtem sídlištních objektů, které jsou navíc rozptýleny ve velkých vzájemných vzdálenostech po celé ploše sídliště (Parma 2015, 250-253). Šance na jejich zachycení v terénu je tak výrazně menší než v případě sídlišt starší doby bronzové. Nejedná se tedy o odraz nižší intenzity osídlení, ale o archeologickou (ne)viditelnost komponenty. 


\subsection{Prostorová distribuce komponent}

Dalším krokem ve zpracování nashromážděných dat byla analýza prostorové distribuce lokalit na úrovni jednotlivých námi sledovaných časových komponent - únětické, věteřovské a mohylové. Toho bylo dosaženo za použití nástroje jádrové hustoty v prostředí programu ArcGis. Rádius vyhledávání vzájemných interakcí jednotlivých lokalit byl zvolen $2 \mathrm{~km}$. Nastavení vychází z teoretických prací zabývajících se ekonomickým zázemím sídelních areálů, kde je takové zázemí chápáno jako oblast o průměru 2-3 km v okolí areálu (Dreslerová 1995, 174; Neustupný 1986, 231; Smrž 1987, 614). V naší studii je toto zázemí chápáno jako oblast užší sociální interakce, nebot mezi sledovanými lokalitami jsou nejen sídelní, ale také pohřební a jiné blíže nespecifikované areály.

Na výsledných mapách je možné identifikovat několik prostorových kumulací, které jsou tvořeny lokálními shluky sídelních, pohřebních a blíže neidentifikovaných areálů aktivit (obr. 11:B-D). Tyto kumulace lze interpretovat jako určité sídelní buňky, jejichž existence je jistě do značné míry ovlivněna geomorfologií krajiny, nikoliv však výhradně. U naprosté většiny lokalit známe jen rámcové datování k jednotlivým archeologickým kulturám, což nám nevypovídá nic o skutečné délce jejich existence a případné koexistenci jednotlivých areálů (srov. Navrátil 2017, 156-158). Přesto má sledování kumulací význam, nebot v případě synchronního výskytu sídelních areálů nám naznačují existenci bližších sociálních vazeb jednotlivých komunit, v případě diachronní existence pak odhalují oblasti, které byly v rámci jednoho časového období opakovaně vyhledávány. Na výsledných mapách můžeme pozorovat, že řada těchto sídelních kumulací vykazuje dlouhodobou kontinuitu např́ič celým sledovaným úsekem doby bronzové.

Mezi sídelní kumulace, které byly využívány ve všech třech sledovaných obdobích, patří soustava lokalit na katastrech Pasohlávek a Mušova (obr. 11:B-D:1). Minimálně v únětickém úseku je možné existenci tohoto shluku spojovat se zatím bohužel jen málo probádaným ohrazeným areálem na vrcholu mušovského Burgstallu. K dalším sídelním kumulacím patří oblast na terasách podél Dyje na katastrech Pavlova a Milovic (obr. 11:B-D:2). Třetím shlukem jsou lokality na katastru Mikulova (obr. 11:B-D:3) a čtvrtým pak lokality na katastru Bulhar (obr. 11:B-D:4). Samostatnou buňku tvoří kumulace aktivit na katastru Klentnice a Perné, které př́mo souvisejí s geomorfologicky výraznými výšinnými lokalitami na Tabulové hoře a Kotli a s lokalitami v jejich zázemí (obr. 11:B-D:5). Výrazně se zde projevuje koncentrace mohylových pohřebních areálů.

$\mathrm{Na}$ úrovni jednotlivých lokalit je kontinuita využivání areálů v průběhu celé starší a střední doby bronzové doložena pouze ve čtyřech případech a z toho pouze na dvou sídelních areálech (Pavlov - Horní pole, Pavlov - Dolní pole). Třetím případem je lokalita ne zcela jasného, ale jistě výjimečného významu související $\mathrm{s}$ dnes již odtěženými jeskyněmi v poloze Mikulov - Turold (Oliva 2020), čtvrtým pak aktivity zachycené detektorovou prospekcí na lokalitě Perná - Kotel. Kontinuitu mezi únětickým a věteřovským obdobím lze $\mathrm{v}$ rámci sídelních areálů sledovat v devíti případech. Mimo výše zmíněné čtyři lokality jsou to ještě Pasohlávky - Poloostrov I, Mušov - U propusti, Mušov - U sv. Jana, Dolní Věstonice - Štěrkovna, Bulhary - Gajdošova cihelna a Mikulov - Kamenné. Kontinuita sídelních areálů mezi věteřovským a mohylovým obdobím je doložena pouze na dvou výše zmíněných lokalitách na katastru Pavlova. Je nutné upozornit, že tuto kontinuitu je třeba chápat pouze schematicky na úrovni námi sledovaných časových horizontů. Jak ukazují příklady podrobnější analýzy materiálu z jednotlivých sídlišst, na kterých se vyskytují dvě chronologicky následné komponenty, nemusí se vždy jednat o kontinuitu faktickou (Navrátil 2017, 156-158). 


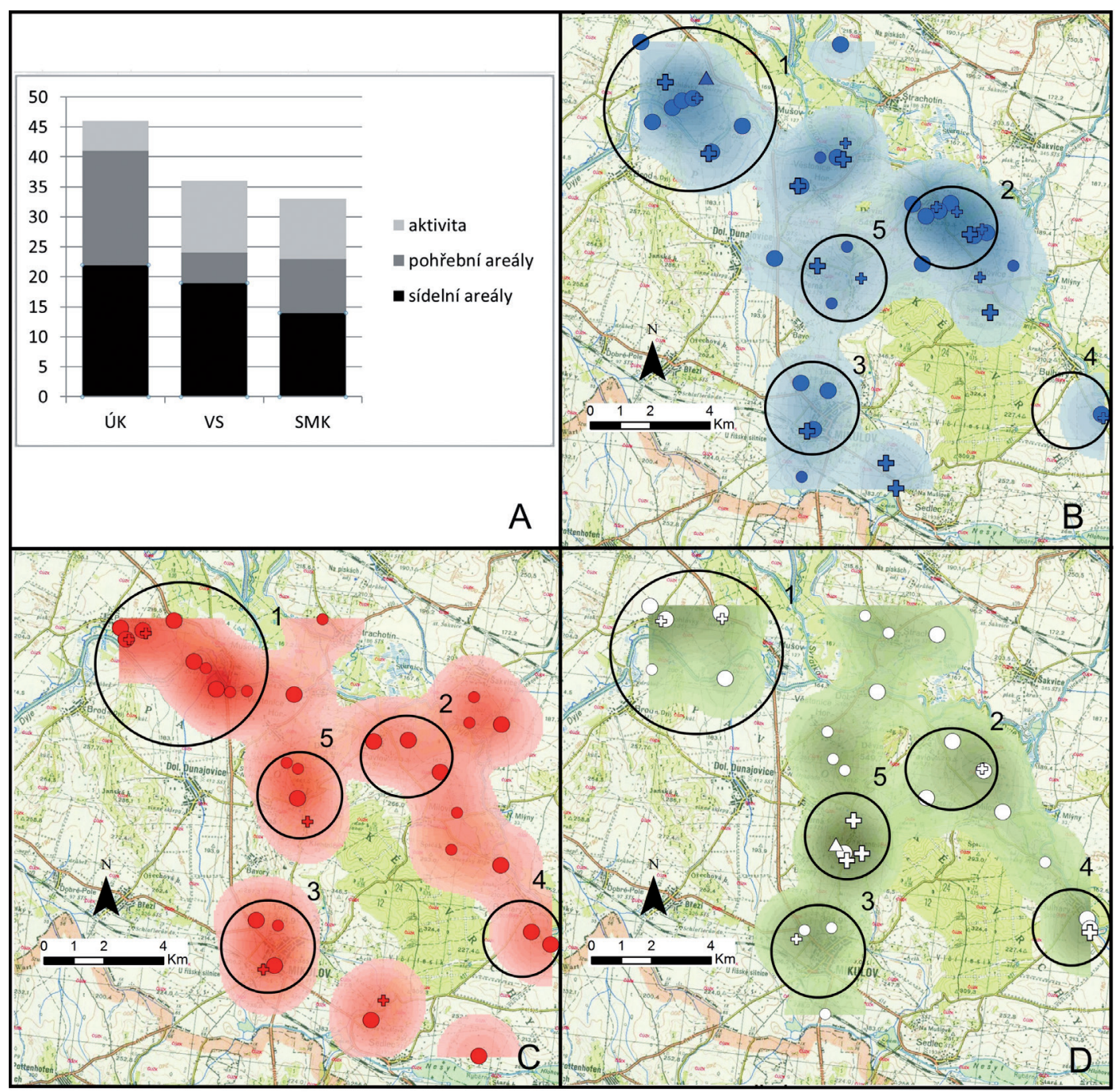

Obr. 11. A: kvantitativní zastoupení komponent, B: prostorová distribuce únětických komponent, C: prostorová distribuce věteřovských komponent, D: prostorová distribuce mohylových komponent (zdroj podkladové mapy: ČÚZK).

Fig. 11. A: quantification of the components, B: spatial distribution of the Únětice component, C: spatial distribution of the Věteřov component, D: spatial distribution of the tumulus component (map source: ČúZK). 


\section{Závěr}

Na základě bohatých archeologických dat z Pavlovských vrchů a jejich okolí jsme se pokusili sledovat vývoj a strukturu osídlení mikroregionu ve starší a střední době bronzové. Na úrovni mikroregionu je možné identifikovat několik sídelních buněk, které jsou tvořeny lokálními shluky komponent. Zatímco některé buňky přetrvávají po celou starší a střední dobu bronzovou (Pasohlávky - Mušov, Pavlov - Milovice, Mikulov, Bulhary, Klentnice - Perná), jiné se váží pouze na dvě, nebo jednu časovou komponentu. Za zvláštní pozornost stojí výrazný shluk lokalit na katastrech obcí Pasohlávky a Mušov, který naznačuje silnou vazbu únětické komponenty na ohrazené výšinné sídliště na lokalitě Mušov - Burgstall. O této únětické lokalitě s potenciálem centrálního významu máme doposud bohužel jen velmi kusé informace (Komoróczy - Červák - Musil 1997).

$\mathrm{Na}$ úrovni jednotlivých lokalit je kontinuita (společný výskyt následných časových komponent) spíše vzácným jevem, který se projevuje výrazněji mezi únětickou a věteřovskou komponentou a jen výjimečně mezi věteřovskou a mohylovou.

Prezentovaná data naznačují také specifický charakter sídelní buňky v prostoru samotných Pavlovských vrchů. Archeologické nálezy z katastru Klentnice a Perné dokládají, že pálavské kopce a jejich bezprostřední okolí byly ve starší i střední době bronzové využívány. Charakter těchto aktivit však zůstává nejasný. Systematický výzkum výšinného sídliště na Tabulové hoře v 50. letech vydal málo početný a nevýrazný materiál ze starší doby bronzové. Doložil také ohrazení ze střední doby bronzové, avšak jen s minimem doprovodných nálezů. Na sousedním výšinném sídlišti v poloze Perná - Kotel máme aktivity ze starší a střední doby bronzové doloženy pouze jednotlivými předměty z detektorových prospekcí. Nálezy z prospekční a záchranné činnosti poukazují také na sídelní aktivity v bezprostředním zázemí obou zmíněných výšinných poloh (Klentnice - Za hřbitovem, Perná - Pod lomem). Nápadná je lokální koncentrace pohřební komponenty, a to zejména v mohylovém období, kdy jsou na katastru Klentnice doloženy minimálně tři pohřební areály. Mohylové pohřby v Klentnici vykazují známý trend, kterým je obecně velmi špatný stav zachování kosterních pozůstatků a nálezových situací. Tento stav je do značné míry zapříčiněn malou hloubkou uložení pohřbů, která u sledovaných případů činila nejčastěji $30-40 \mathrm{~cm}$, v ojedinělých případech až $60 \mathrm{~cm}$.

Jisté indicie o charakteru aktivit v oblasti Tabulové hory a Kotle nám může napovědět rozdíl mezi strukturou archeologických památek v prostoru Pavlovských vrchů a památkami v nižších polohách u jejich paty. Mimo nevýrazný keramický materiál datovatelný do únětického období pochází z Tabulové hory pravděpodobně také dva jedinečné depoty zlatých vlasových ozdob (Stuchlik 2018). V mohylovém období (respektive jeho mladší fázi) byla Tabulová hora nejspíše ohrazena, doklady o intenzivních sídelních aktivitách však chybí. V bezprostředním zázemí lokality se přitom vyskytuje výrazná koncentrace několika pohřebních areálů. Tato skromná data poukazují na slabé zastoupení sídelní složky a zároveň na nápadnou koncentraci votivních a pietních aktivit. Naopak v nižších polohách vytvářejí lokality o poznání hustší shluky běžných sídlišt na terasách podél Dyje a v jiných příznivých polohách.

Charakter památek na Pálavě v kombinaci $\mathrm{s}$ nepřehlédnutelnou geomorfologií $\mathrm{v}$ podobě výrazného vápencového bradla tak nabízí interpretaci oblasti coby aktivně využívané sakrální krajiny. Vazba sakrálních a symbolických aktivit na výrazné geomorfologické a zvláštní prvky v krajině je dobře zdokumentovaným jevem jak v archeologických tak i historických pramenech (Bradley 2017, 160d.; Dufková 1999; Matoušek 
1991; 1999). V únětickém prostředí poukazuje na takové vazby např́íklad lokální koncentrace depotů na Slané hoře u Slaného s doloženou existencí slaných pramenů a puklinových jeskyň (Kubánek 2010, 257; Stuchlik 2018, 166), nebo nález depotu hřiven v prostoru nápadného vápencového hřbetu zvaného Šibeničních přímo na katastru Mikulova (Ondráček 1958). Poměrně sporadický výskyt únětický aktivit na Pálavě stojí přitom v nápadném kontrastu $\mathrm{s}$ výrazným shlukem únětických sídelních a pohřebních komponent v blízkém okolí výšinného ohrazeného sídliště Mušov - Burgstall. Jednou z možných interpretací prezentovaných dat je, že právě na Burgstallu se ve starší době bronzové nacházelo hlavní socio-ekonomické centrum oblasti, zatímco Tabulová hora hrála roli především symbolickou.

Je pochopitelně oprávněný argument poukazující na skutečnost, že jsou to praktické faktory související s geomorfologií krajiny, které ovlivňují strukturu a charakter osídlení. Je to ovšem také právě geomorfologie, která hrála klíčovou roli v lidském vnímání krajiny a jejího sociálního a symbolického významu. Není proto správné automaticky vylučovat jeden aspekt druhým, ale naopak je třeba chápat tyto aspekty jako spojité nádoby. Kontinuita symbolického významu Pavlovských vrchů je patrná i v následujícím období popelnicových polí, nebot aktuální data zde dokládají existenci další z řady makrokumulací kovových depozit, které se vážou na výrazné prvky v krajině, na komunikační koridory, či centrální lokality - tentokráte však v doprovodu výrazné sídelní složky (Navrátil 2021; Navrátil - Bísko - Tencer 2020).

\section{Poděkování}

Rád bych na tomto místě poděkoval Mgr. Davidu Cibulkovi za poskytnutí informací o aktuální situaci ohledně záchranných archeologických výzkumů na katastru Pasohlávek a Mušova. Díky patří také Mgr. Kristíně Piačkové a Mgr. Františku Trampotovi, Ph.D. za pomoc při aktualizaci informací týkajících se lokalit z katastru Mikulova.

\section{Seznam lokalit}

V seznamu lokalit (číslování lokalit podle obr. 10) jsou uváděny souřadnice bodů reprezentujících jednotlivé lokality za použití souřadnicového systému S-JSTK Krovak East North. Body byly vybrány tak, aby co nejlépe charakterizovaly lokalizaci místa nálezu. V celé řadě případů však přesná lokalizace není známa. U těch lokalit, kde není možné nálezy či objekty přesněji lokalizovat, je uvedena přesnost zaměření „do 100 m“. U lokalit, které se nacházely v jedné trati a ve vzájemné blízkosti, a kde zároveň bylo zřejmé, že tvoří oddělené polohy, je uvedena poznámka „více poloh“.

\section{Pasohlávky - Lopota}

Souřadnice: -606 741, -1 191205 (přesnost do 100 m) Druh nálezu: Únětický hrob - meliorací narušený nedatovaný objekt a únětický hrob.

Literatura: Jelínková 1987, 245-246.

\section{Pasohlávky - Za stanicí}

Souřadnice: -606 440, -1 192205 (přesnost do $100 \mathrm{~m}$ ) Druh nálezu: Mohylové sídliště - sídlištní jáma s keramikou, mazanicí a drtidlem.

Literatura: Jelínková 1987, 245.

\section{Pasohlávky - U hřbitova}

Souřadnice: 605 940, -1 192626 (přesnost do 100 m, více poloh)

Druh nálezu: Únětické pohřebiště a mohylové sídliště - nepublikovaný výzkum Archeologického ústav Brno. Náhodný nález mohylového hrobu z roku 1926.

Literatura: Informace Davida Cibulky. Furmánek 1973, 80. 


\section{Pasohlávky - U vodárny}

Souřadnice: -605 860, -1 192896 (přesnost do 10 m)

Druh nálezu: Věteřovské sídliště se 14 objekty a věteřovský hrob v pithu.

Literatura: Navrátil 2017, 51-52, 92; Stuchlík 2007.

\section{Pasohlávky - Poloostrov I}

Souřadnice: -605 670, -1 193404 (přesnost do $10 \mathrm{~m}$ ) Druh nálezu: Únětické a věteřovské sídliště - sídlištní jámy narušené výkopem kanalizace.

Literatura: Navrátil 2007.

\section{Pasohlávky - Poloostrov II/ Za kravínem} Souřadnice: -605 336, -1 193174 (přesnost do $10 \mathrm{~m}$ ) Druh nálezu: Únětické sídliště - polykulturní sídliště odkryto v rámci nepublikovaného ZAV ARÚB.

Literatura: Cibulka 2015.

\section{Pasohlávky - Za Tuchnou}

Souřadnice: -605 016, -1 193109 (přesnost do 10 m) Druh nálezu: Únětické sídliště a hrob, věteřovské sídliště a hrob - polykulturní pohřebiště.

Literatura: Komorćzy - Klanicová - Navrátil - Sázelová - Vlach2010.

\section{Brod nad Dyjí - Na dolině}

Souřadnice: -606 347, -1 193891 (přesnost do 100 m)

Druh nálezu: Únětické sídliště - sídlištní jáma na polykulturním sídlišti.

Literatura: Jelínková 1991, 123

\section{Brod nad Dyjí - Pod mušovskou cestou}

Souřadnice: -606 394, -1 194307 (přesnost do 100 m) Druh nálezu: Mohylová aktivita - keramický depot 6 šálků, džbánku a zbytků zásobnice.

Literatura: Jelínková 1991, 125.

\section{Mušov - Hradisko}

Souřadnice: -604 532, -1 192422 (přesnost do 10 m)

Druh nálezu: Únětické hradiště - sídlištní keramický materiál z kulturní vrstvy, příkop.

Literatura: Komoróczy - Červák - Musil 1997.

\section{Mušov - Neurissen II}

Souřadnice: -604 082, -1 192419 (přesnost do 10 m) Druh nálezu: Mohylové sídliště - polykulturní sídliště s mohylovými objekty.

Literatura: Bálek - Šedo 1997, 177.

\section{Mušov - Neurissen III}

Souřadnice: -604 065, -1 192670 (přesnost do 10 m) Druh nálezu: Mohylový hrob a věteřovské sídliště polykulturní sídliště a pohřebiště.

Literatura: Komorćzy - Klanicová - Navrátil - Sázelová - Vlach2010.

\section{Mušov - Štěrkovna}

Souřadnice: -604 346, -1 194890 (přesnost do 10 m) Druh nálezu: Únětické pohřebiště a sídliště - pohřebiště s 35 hroby, 3 sídlištní objekty na polykulturním sídlišti.

Literatura: Stuchlík 1987.

\section{Mušov - Mezi mlýnem a štěrkovnou}

Souřadnice: -603 936, -1 194619 (přesnost do 100 m) Druh nálezu: Mohylové sídliště - dva objekty na polykultruním sídlišti. V jednom objektu uložen bronzový depot.

Literatura: Stuchlík 1981.

\section{Mušov - U propusti}

Souřadnice: -603 394, -1 194043 (přesnost do 100 m) Druh nálezu: Únětické a věteřovské sídliště - zahloubené objekty na polykulturním sídlišti.

Literatura: Jelínková 1986, 234.

\section{Mušov - U mlýna}

Souřadnice: -602 997, -1 194255 (přesnost do 100 m) Druh nálezu: Věteřovská aktivita - střepy z kulturní vrstvy na polykulturním sídlišti.

Literatura: Stuchlík 2002, 202.

\section{Mušov - U sv. Jana}

Souřadnice: -602 660, -1 194956 (přesnost do 100 m) Druh nálezu: Únětické a věteřovské sídliště - jeden únětický objekt a 19 objektů věteřovských. Literatura: Geisler - Stuchlíková 1986.

\section{Mušov - Záhumenky u Dyje}

Souřadnice: -602 177, -1 195049 (přesnost do 100 m) Druh nálezu: Věteřovská aktivita - střepový materiál z povrchového sběru.

Literatura: Komorćzy - Klanicová - Navrátil - Sázelová - Vlach 2010. 


\section{Horní Věstonice - Na lukách}

Souřadnice: -601 615, -1 195029 (přesnost do 100 m)

Druh nálezu: Věteřovská aktivita - nálezy střepového materiálu z narušených objektů.

Literatura: Měřínský - Peškař - Rakovský 1980.

\section{Horní Věstonice - Zelnice}

Souřadnice: -600 702,201 -1 195088 (přesnost do 100 $\mathrm{m})$

Druh nálezu: Únětické sídliště - jeden únětický objekt nepravidelného tvaru.

Literatura: Stuchlík 2002, 197.

\section{Horní Věstonice - Pole SZ od obce}

Souřadnice: -601 370, -1 196028 (přesnost do 10 m)

Druh nálezu: Únětické pohřebiště a sídliště - 5 únětických hrobů a jedna sídlištní jáma.

Literatura: Stuchlík 2006.

\section{Horní Věstonice - Intravilán}

Souradnice: -600 510, -1 196405 (přesnost do 100 m)

Druh nálezu: Mohylová aktivita - ojedinělý nález bronzové sekery.

Literatura: К̌́íhovský 1992, 288-289.

\section{Horní Věstonice - J část katastru obce/Pod Martinkou}

Souřadnice: -600 305, -1 197304 (přesnost do 100 m)

Druh nálezu: Věteřovská a mohylová aktivita - ojedinělý nález bronzové dýky a jehlice s kulovitou hlavicí.

Literatura: Stuchlík 2002, 198.

\section{Dolní Věstonice - Štěrkovna}

Souřadnice: -600 047, -1 195122 (přesnost do 100 m) Druh nálezu: Únětické pohřebiště a únětické a věteřovské sídliště - polykulturní naleziště s 56 únětickými hroby, 3 únětickými a 17 věteřovskými objekty.

Literatura: Dvořák - Rakovský - Stuchlíková - Peška 1990.

\section{Dolní Věstonice - Na pískách}

Souřadnice: -599 862, -1 194599 (přesnost do 100 m) Druh nálezu: Únětický hrob - nádoby a vlasové ozdoby ze zničeného hrobu.

Literatura: Stuchlík 2002, 195.

\section{Dolní Věstonice - Intravilán V}

Souřadnice: -598 856, -1 195055 (přesnost do $100 \mathrm{~m}$ ) Druh nálezu: Mohylové sídliště - 4 sídlištní jámy.

Literatura: Čižmář - Geisler - Himmelová - Rakovský 1982.

\section{Pouzdřany - Dolní nivy}

Souřadnice: -600 040, -1 191298 (přesnost do 100 m) Druh nálezu: Únětické sídliště - 2 jámy.

Literatura: Stuchlík 2002, 213.

\section{Strachotín - Pískovna}

Souřadnice: -599 088, -1 192608 (přesnost do 100 m) Druh nálezu: Věteřovská a mohylová aktivita - keramický materiál z kulturní vrstvy.

Literatura: Měřínský 1985, 214.

\section{Strachotín - Intravilán}

Souřadnice: -598 459, -1 193084 (přesnost do 100 m)

Druh nálezu: Mohylová aktivita - ojedinělý nález keramické nádoby.

Literatura: Měřínský 1985, 218.

\section{Strachotín - Štěrkovna}

Souřadnice: -596 845, -1 193124 (přesnost do 100 m)

Druh nálezu: Mohylové sídliště - 30 sídlištních objektů.

Literatura: Měřínský 1985, 215-216; Říhovský 1982, tab. 28-33.

\section{1. Šakvice - Zelničky}

Souřadnice: -594 014, -1 195241 (přesnost do 100 m) Druh nálezu: Věteřovská aktivita - keramický materiál z povrchového sběru.

Literatura: Unger 1985, 28.

\section{2. Šakvice - Rybník}

Sour̆adnice: -594 173, -1 196094 (přesnost do 100 m) Druh nálezu: Věteřovská aktivita - střepový materiál z povrchového sběru.

Literatura: Unger 1985, 28-29.

\section{3. Šakvice - Bílé břehy}

Souřadnice: -593 102, -1 196140 (přesnost do 100 m) Druh nálezu: Věteřovské sídliště - objekty na polykulturním sídlišti.

Literatura: Dvořák - Rakovský - Stuchlíková - Peška 1990, 89. 


\section{Pavlov - Hřbitov}

Souřadnice: -597 626, -1 196643 (přesnost do 100 m) Druh nálezu: Únětické sídliště - 2 nádoby, střepy a zvířecí kosti z objektu.

Literatura: Stuchlík 2002, 211.

\section{Pavlov - Náves}

Souřadnice: -597 381, -1 196696 (přesnost do $100 \mathrm{~m}$ ) Druh nálezu: Věteřovské sídliště - 1 jáma s keramickým materiálem.

Literatura: Stuchlík 2002, 210.

\section{Pavlov - Nad silnicí}

Souřadnice: -596 753, -1 196861 (přesnost do 100 m) Druh nálezu: Únětické pohřebiště a sídliště - tři hroby a jeden sídlištní objekt.

Literatura: Stuchlík 1992, 240-241, obr. 7:9-11.

\section{Pavlov - Horní pole}

Souřadnice: -596 349, -1 196603 (přesnost do 10 m) Druh nálezu: Únětické (44 objektů), věteřovské (44 objektů) a mohylové sídliště, únětický hrob rozsáhlé polykulturní sídliště s jedním únětickým hrobem v rámci protoúnětického pohřebiště.

Literatura: Navrátil 2017; Stuchlík 2002,209-210.

\section{Pavlov - JV okraj obce}

Souřadnice: -597 170, -1 197053 (přesnost do $100 \mathrm{~m}$ )

Druh nálezu: Únětické sídliště - střepy z narušeného objektu.

Literatura: Ř́hovský 1966.

\section{Pavlov - Cihelna}

Souřadnice: -597 189, -1 198614 (přesnost do 100 m)

Druh nálezu: Únětické a mohylové sídliště - keramika a kostěné nástroje $\mathrm{z}$ narušených objektů během těžby.

Literatura: Stuchlík 2002, 212.

\section{Pavlov - Dolní pole}

Souřadnice: -595 152, -1 197609 (přesnost do 100 m, více poloh)

Druh nálezu: Únětické a věteřovské sídliště, únětické pohřebiště a mohylový hrob.

Literatura: Stuchlík 2002, 209.

\section{Milovice - U topolů}

Souřadnice: -595 298, -1 197701 (přesnost do 100 m)

Druh nálezu: Mohylové sídliště a únětická aktivita - 2 mohylové objekty a únětické střepy z kulturní vrstvy.

Literatura: Stuchlík 2002, 199.

\section{Milovice - Areál hospodářských budov}

Souřadnice: -595 357, -1 199097 (přesnost do 100 m) Druh nálezu: Únětický hrob.

Literatura: Stuchlík 2002, 201.

\section{Milovice - Na pískách}

Souřadnice: -594 252, -1 198707 (přesnost do 100 m) Druh nálezu: Únětická aktivita - nádoba a střepy ze starších výzkumů, žlab.

Literatura: Čižmář - Geisler - Himmelová - Rakovský 1982, 59.

\section{Milovice - Prostřední pole}

Souřadnice: -594 649, -1 199090 (přesnost do 100 m) Druh nálezu: Věteřovská a mohylová aktivita - střepy z kulturní vrstvy.

Literatura: Čižmář - Geisler - Himmelová - Rakovský 1982, 60.

\section{Milovice - Spitzhübel}

Souřadnice: -595 033, -1 200281 (přesnost do 100 m) Druh nálezu: Únětické pohřebiště a věteřovská aktivita - keramika ze zničených únětických hrobů a věteřovská keramika z kulturní vrstvy.

Literatura: Stuchlík 2002, 200.

\section{Bulhary - Pustý zámek}

Souřadnice: -593 121, -1 200843 (přesnost do 100 m) Druh nálezu: Věteřovské sídliště a mohylová aktivita

- keramika z věteřovského objektu a z kulturní vrstvy.

Literatura: Klanicová - Peška - Vitula 1994, 221-222.

\section{Bulhary - Podyjí}

Souřadnice: -591 818, -1 202662 (přesnost do 100 m)

Druh nálezu: Únětické sídliště a mohylová aktivita - polykulturní lokalita narušovaná výstavbou rodinných domů.

Literatura: Klanicová - Peška - Vitula 1994, 214. 


\section{Bulhary - Au Äcker}

Souřadnice: -591 732, -1 202986 (přesnost do 100 m, více poloh)

Druh nálezu: Věteřovské a mohylové sídliště a mohylové pohřebiště - polykulturní lokalita narušovaná různými stavebními zásahy.

Literatura: Klanicová - Peška - Vitula 1994, 212-213.

\section{Bulhary - Gajdošova cihelna}

Souřadnice: -591 302, -1 203694 (přesnost do 100 m, více poloh)

Druh nálezu: Únětické a věteřovské sídliště a únětic-

ký hrob - ohrazená polykulturní lokalita zničená cihelnou.

Literatura: Klanicová - Peška - Vitula 1994, 209-210.

\section{Dolní Dunajovice - JV okraj obce}

Sour̆adnice: -602 243, -1 198476 (přesnost do $100 \mathrm{~m}$ )

Druh nálezu: Únětické sídliště - 8 sídlištních objektů

Literatura: Klíma 1980.

\section{Perná - Feigelberg}

Souřadnice: -600 804, -1 198709 (přesnost do 100 m)

Druh nálezu: Únětické pohřebiště.

Literatura: Nálezová zpráva ARÚB č. 1055/51 (K. Tihelka); 1355/74 (M. Šolle).

\section{Perná - Pod lomem}

Souřadnice: -599 904, -1 198603 (přesnost do 100 m) Druh nálezu: Věteřovské sídliště - 20 objektů odkryto během záchranného výzkumu v roce 1988.

Literatura: Rakovský - Peška - Vitula 1991.

\section{Perná - Kotel}

Sour̃adnice: -599 925, -1 197672 (přesnost do 10 m, více poloh)

Druh nálezu: Věteřovská a mohylová aktivita - ojedinělé nálezy z povrchových sběrů.

\section{Literatura: -}

\section{Klentnice - Pod hotelem}

Souřadnice: -599 290, -1 199513 (přesnost do $100 \mathrm{~m}$ )

Druh nálezu: Únětický hrob - povrchový nález keramiky a části lebky nejpravděpodobněji z narušeného kostrového hrobu.

Literatura: Nálezová zpráva ARÚB č. 327/58 (J. Ondráček).

\section{Klentnice - S konec obce}

Souřadnice: -599 629, -1 199376 (přesnost do 10 m)

Druh nálezu: Věteřovský hrob a mohylové pohřebišš

- pohřebiště z průběhu celé doby bronzové.

Literatura: Říhovský 1965; Stuchlíková 1990.

\section{Klentnice - Tabulová hora}

Souřadnice: -600 232, -1 200180 (přesnost do $10 \mathrm{~m}$ ) Druh nálezu: Únětická aktivita a mohylové hradiště

- výšinné sídliště s nálezy střepů a detektorových nálezů z kulturní vrstvy.

Literatura: К̌́íhovský 1955.

\section{Klentnice - Pod skálou}

Druh nálezu: Mohylový hrob - náhodný nález při stavbě vodojemu.

Literatura: Nálezová zpráva ARÚB 794/49; Furmánek 1973, 56.

\section{Klentnice - Nad hřbitovem}

Souřadnice: -599 957, -1 200466 (přesnost do 10 m)

Druh nálezu: Věteřovská aktivita a mohylové sídliště

- bohatý materiál z povrchových a detektorových sběrů.

Literatura: nepublikováno

\section{Klentnice - Přední hony}

Souřadnice: -599 873, -1 200713 (přesnost do $100 \mathrm{~m}$ )

Druh nálezu: Mohylové pohřebiště - orbou narušené hroby a jednotlivé nálezy z detektorové prospekce.

Literatura: Nálezová zpráva ARÚB č. 773/60 (J. Ř́íhovský).

\section{Klentnice - U kapličky; Záhumenky}

Souřadnice: -599 365, -1 200483 (přesnost do 100 m)

Druh nálezu: Mohylové pohřebiště - 5 mohylových pohřbů narušených výkopem pro kanalizaci.

Literatura: Nálezová zpráva ARÚB č.1053/58 (J. Říhovský).

\section{Mikulov - Kamenné}

Souřadnice: -601 358, -1 202626 (přesnost do $10 \mathrm{~m}$ )

Druh nálezu: Únětické a věteřovské sídliště - větší sídliště odkryté při záchranném výzkumu.

Literatura: Kleinová 2010; Navrátil 2017. 


\section{Mikulov - Turold}

Souřadnice: -600 461, -1 202896 (přesnost do 100 m) Druh nálezu: Únětická, věteřovská a mohylová aktivita - početné nálezy z vápencového lomu.

Literatura: Stuchlíková - Stuchlík 1982.

\section{Mikulov - Nad brněnskou silnicí}

Souřadnice: -601 278, -1 203031 (přesnost do 100 m)

Druh nálezu: Mohylové sídliště - starší nález objektu

s keramikou.

Literatura: Jüttner 1928.

\section{Mikulov - V trojúhelníku}

Souřadnice: -601 531, -1 203343 (přesnost do $10 \mathrm{~m}$ )

Druh nálezu: Mohylový hrob - dvojhrob s kamennou konstrukcí.

Literatura: Šabatová - Parma - Trampota - Jarošová

- Kaňáková - Přichystal - Vargová - Vymazalová 2020.

\section{Mikulov - Kowalského pískovna}

Souřadnice: -601 158, -1 204240 (přesnost do 100 m) Druh nálezu: Únětické pohřebiště a věteřovský hrob - únětické pohřebiště ničené pískovnou. Vyskytl se také jeden pohřeb v pithu.

Literatura: Tihelka 1953, 298; Jüttner 1950; Unger 1971a; Piačková 2020

66. Mikulov - Ul. 22. dubna.

Souřadnice: -600 943, -1 204176 (přesnost do 10 m) Druh nálezu: Únětické sídliště - zahloubené objekty na polykulturním sídlišti.

Literatura: Piačková 2012.

\section{Mikulov - Poliklinika}

Souřadnice: -600 943, -1 204176 (přesnost do 100 m) Druh nálezu: Věteřovské sídliště - 5 narušených sídlištních objektů.

Literatura: Peška - Klanicová 1996.

\section{Mikulov - Die Brennhügel}

Souřadnice: -600 578, -1 205851 (přesnost do 100 m)

Druh nálezu: Mohylová aktivita - ojedinělý nález bronzové dýky.

Literatura: Trampota 2012.

\section{Mikulov - Šibeničník}

Souřadnice: -601 332, -1 205756 (přesnost do 100 m) Druh nálezu: Únětická aktivita - depot hřiven.

Literatura: Ondráček 1958.

70. Mikulov - Na Rybníkách; Nad valtickou silnicí; Czujanova pískovna

Souřadnice: -598 530, -1 205303 (přesnost do $100 \mathrm{~m}$ ) Druh nálezu: Únětické pohřebiště - rozsáhlé pohřebiště.

Literatura: Tihleka 1953, 289. Unger 1971b; Piačková 2020.

\section{Mikulov - U vodárny}

Souřadnice: -598 165, -1 206161 (přesnost do 100 m) Druh nálezu: Únětické pohřebiště - 4 únětické hroby.

Literatura: Tihelka 1953, 298. Piačková 2020, 77.

72. Mikulov - Na Mušlově; Triasovo pole; Triasfeld Souřadnice: -597 459, -1 206042 (přesnost do 100 m) Druh nálezu: Věteřovské sídliště - sídliště narušené

těžbou písku - prozkoumány 4 objekty.

Literatura: Peška - Klanicová 1993b; Kubín 2006.

73. Mikulov - Pod Vysokým rohem; Serpentiny; Lehmgrubenäcker

Souřadnice: -597 046, -1 205383 (přesnost do 100 m) Druh nálezu: Věteřovský hrob - vyoraná nádoba s pohřbem.

Literatura: Jüttner 1950, 366.

\section{Sedlec - Koldberky}

Souřadnice: -593 863, -1 207240 (přesnost do 100 m) Druh nálezu: Věteřovské sídliště - neohrazené sídliště na vyvýšenině.

Literatura: Unger 1969; Peška - Klanicová 1993a; Laštíková 2010. 


\section{Bibliografie}

Bálek, M. - Šedo, O. 1997: Mušov (k. ú. Pasohlávky, okr. Břeclav). Přehled výzkumů 1993-1994, 177178.

Benkovksky-Pivovarová, Z. 2001: Datovanie konca nitranskej kultúry vo svetle rádiokarbónových dát z Jelšoviec. Pravěk Nová řada 11, 221-231.

Benkovsky-Pivovarová, Z. 2005: Zur Absenz der Gräber der Věteřov-Kultur in Mähren. Pravěk Nová řada 15, 255-262.

Bradley, R. 2017: A Geography of Offerings: Deposits of Valuables in the Landscape of Europe. Oxford: Oxbow Books.

Cibulka, D. 2015: Sídlištní jámy starší doby bronzové s lidskými pozůstatky v Pasohlávkách. Nepub. dip. práce. Brno: Masarykova univerzita.

Čižmář, I. - Geisler, M. - Himmelová, Z. - Rakovský, I. 1982: Rettungsgrabungen der prähistorischen Abteilung am Baue des unteren Stausees des Wasserwerkes Nové Mlýny im Jahre 1980 (Bez. Břeclav). Přehled výzkumů 1980, 59-60.

Dreslerová, D. 1995: A settlement-economic model for a prehistoric microregion: settlement activities in the Vinoř-stream basin during the hallstatt period. In: M. Kuna - N. Venclová (eds.): Whither archaeology? Papers in honour of Evžen Neustupný. Praha, 145-160.

Dufková, M. 1999: Hora a jeskyně ve starověkých pramenech. Archeologické rozhledy 51, 457-467.

Dvořák, P. - Rakovský, I. - Stuchliková, J. - Peška, J. 1990: Rettungsgrabungen auf dem Bau des Wasserwerkes Nové Mlýny im Jahre 1987 (Bez. Břeclav). Přehled výzkumů 1987, 89.

Furmánek, J. 1973: Brnzová industrie středodunajské mohylové kultury na Moravě. Slovenská archeológia 21, 25-145.

Geisler, M. - Stuchliková, J. 1986: Věteřovské sídliště v Mušově. Archeologické rozhledy XXXVIII, 121-138.

Goláñová, P. 2017: The Pálava Hills during the La Tène period. In: J. Kysela - A. Danielisová - J. Militký: Stories that made the Iron Age. Praha: Archeologický ústav AV ČR, Praha.

Holubová, Z. - Navrátil, A. 2020: Nové poznatky k halštatskému osídlení Pálavy. In: I. Čižmář - H. Čižmářová - A. Humpolová: Jantarová stezka v pro- měnách času. Brno: Moravské zemské muzeum, 21-31.

Jelinková, D. 1986: Archeologické lokality na katastru obce Mušov (10040) (okr. Břeclav). Jižní Morava 22, 227-242.

Jelinková, D. 1987: Archeologické lokality na katastru obce Pasohlávky. Jižní Morava 23, 241-249.

Jelinková, D. 1991: Archeologické lokality na katastru obce Brod nad Dyjí (01254) okr. Břeclav. Jižní Morava $27,121-126$.

Jüttner, K. 1928: Eine bronzezeitliche Wohngrube aus der Gegend von Nikolsburg (Mähren). Sudeta IV, 59-60.

Jüttner, K. 1950: Únětické (věteřovské) pohřby v nádobách na Jižní Moravě. Obzor prehistorický XIV, 365-366.

Jüttner, R. - Matzura, J. - Petak, A. 1925: Ein südmärischer Fund aus der Mönitzer Zeit. Sudeta 1, 131-136.

Klanicová, E. - Peška, J. - Vitula, P. 1994: Archeologické lokaltiy na katastru obce Bulhary (01616). Jižní Morava 30, 205-224.

Kleinová, K. 2010: Pravěký sídelní areál z lokality Mikulov - Kamenné. Nepub. bak. práce. Olomouc: Univerzita Palackého v Olomouci.

Klíma, B. 1980: Únětické sídliště u Dolních Dunajovic (okr. Břeclav). Přehled výzkumů 1977, 33-34.

Koch, M. 1853: Bericht über Alterthümer im Nikolsburger Bezirk. Schriften der hitorisch-statistischen Section der k.k.m. schl. Gesellschaft des Ackerbaues, der Natur- und Landeskunde V, 25-29.

Komoróczy, B. - Červák, P. - Musil, J. 1997: Mušov (k. ú. Pasohlávky, okr. Břeclav). Přehled výzkumů 1993-1994, 169-175.

Komoróczy, B. - Klanicová, S. - Navrátil, A. - Sázelová, S. - Vlach, M. 2010: Pasohlávky (k. ú. Mušov, k. ú. Pasohlávky, okr. Břeclav), Přehled výzkumů 51, 348-356.

Kubánek, V. 2010: Královské město Slaný na pozadí historie (I.). Brno: Vladimír Kubánek.

Kubin, P. 2006: Mikulov (okr. Břeclav), Přehled výzkumů 47, 145.

Kytlicová, O. 2007: Jungbronzezeitliche Hortfunde in Böhmen. Prähistorische Bronzefunde XX/12. Stuttgart: Franz Steiner Verlag

Laštiková, L. 2010: Starobronzové sídliště věteřovské kultury z lokality Sedlec - Koldberky. Nepub. bak. práce. Olomouc: Univerzita Palackého v Olomouci. 
Massy, K. - Stockhammer, P. W. 2019: Testing Reinecke's chronology of the Early Bronze Age with radiocarbon dating - New evidence from Southern Bavaria. Studia Hercynia XXIII/2, 22-35.

Matoušek, V. 1991: Čtení o teritorialitě. Památky archeologické LXXXII, 366-375.

Matoušek, V. 1999: Hora a jeskyně. Př́íspěvek ke studiu vývoje vztahu člověka a jeho přírodního prostředí v evropě od neolitu do raného středověku. Archeologické rozhledy LI/3, 441-456.

Měřinský, Z. 1985: Archeologická topografie katastrálních území obcí v oblasti vodního díla Nové Mlýny (okres Beřclav). Jižní Morava 21, 205-220.

Měřinský, Z. - Peškař, I. - Rakouský, I. 1980: Archeologické nálezy na pravém břehu Dyje u soutoku se Svratkou (okr. Břeclav). Přehled výzkumů 1977, 109.

Müller, J. 1999: Zur Radiokarbondatierung des Jungbis Endneolithikums und der Frühbronzezeit im Mittelelbe-Saale-Gebiet (4100-1500 v. Chr.). Bericht der Römisch-Germanischen Kommision 80, 31-92.

Naurátil, A. 2007: Věteřovské sídliště v Pasohlávkách - U vodárny v kontextu osídlení mikroregionu. Nepub. dip. práce. Brno: Masarykova univerzita.

Navrátil, A. 2017: Osídlení pod Pavlovskými vrchy v závěru starší doby bronzové. Nepub. dis. práce. Brno: Masarykova univerzita.

Navrátil, A. - Bǐško, R. - Tencer, T. 2020: Hradiště Tabulová hora u Klentnice v době popelnicových polí. Přehled výzkumů $61 / 1,71-85$.

Navrátil, A. 2021: Kovová depozita doby popelnicových polí na Pálavě, Pravěk Nová řada 29, 239-269.

Neustupný, E. 1986: Sídelní areály pravěkých zemědělců. Památky archeologické LXXVII, 226-276.

Novotná, M. 1980: Die Nadeln in der Slowakei. Prähistorische Bronzefunde XIII/6. München: Beck.

Oliva, M. 2020: K lokalizaci archeologických nálezů a zaniklých jeskyň na Turoldu u Mikulova. Acta Musei Moraviae - scientiae sociales 105, 3-11.

Ondráček, J. 1958: Depot z Prušánek a únětické hřivny na Moravě. Pravěk východní Moravy 39.

Ondráček, J. 1962: Únětické pohřebiště u Rebešovic na Moravě. Sborník Československé společnosti archeologické 2, 5-100.

Parma, D. 2015: Poznámky k sídelním strukturám starší a střední doby bronzové na jižní Moravě. In:
J. Bátora - P. Tóth: Ked' bronz vystriedal med'. Nitra: Archeologický ústav slovenskej akadémie vied, 243-260.

Parma, D. - Barta, P. - Jarošová, I. - Kaupová, S. Nývltová-Fišáková, M. - Vargová, L. 2018: A cruel fate? The unique bronze age burial from Ivanovice na Hané (okr. Vyškov/CZ). Archäologisches Korrespondenzblatt 48/3, 323-338.

Peška, J. 1992: Životní prostředí a člověk na počátku doby bronzové na Břeclavsku. XXI Mikulovksé symposium 1991. Brno.

Peška, J. 1995: Die Siedlungsstruktur der Aunjetitzer Kultur un der Věteřov-Gruppe im Bereich der Pollauer Berge (Pavlovské vrchy) in Südmähren. Mem. Museo Cin. St. Nat. Verona, Sez. Scienzeomo 4, 193-201.

Peška, J. 2012: Beispiele der absoluten Chronologie der Frühbronzezit in Mähren und ihrer Verknüpfungen mit der Ägäis. In: R. Kujovský - V. Mitáš (eds.): Václav Furmánek a doba bronzová. Zborník k sedemdesiatym narodeninám. Nitra: Archeologickí ústav Slovenské akadémie vied, 297-314.

Peška, J. 2019: Reinecke's Erbe. Die absolute Chronologie der Frühbronzezeit Mährens - ein Diskussionsansatz. Studia Hercynia XXIII/2, 97-115.

Peška, J. - Klanicová, E. 1993a: Třetí výzkumná sezóna v Sedleci (okr. Břeclav). Přehled výzkumů 1990, 75.

Peška, J. - Klanicová, E. 1993b: Záchranná akce v Mikulově-Mušlově (okr. Břeclav). Přehled výzkumů 1991, 55.

Peška, J. - Klanicová, E. 1996: Věteřovské sídliště v Mikulově (okr. Břeclav). Přehled výzkumů 1992, 49.

Piacková, K. 2012: Únětické sídlisko v Mikulove. Nepub. bak. práce. Brno: Masarykova univerzita.

Piačková, K. 2020: Antropologická analýza kosterních pozůstatků únětické kultury ze sbírek Regionálního muzea v Mikulově. Nepub. bak. práce. Brno: Masarykova univerzita.

Salaš, M. 2005: Bronzové depoty střední až pozdní doby bronzové na Moravě a ve Slezsku. Brno: Moravské zemské muzeum.

Rakovský, I. - Peška, J. - Vitula, P. 1991: Věteřovské a horákovské sídliště v Perné (okr. Břeclav). Přehled výzkumů 1988, 27-28.

Řihovský, J. 1955: Opevněná osada na Tabulové hoře u Klentnice na Moravě. Archeologické rozhledy VII, 28-32. 
Řihovský, J. 1957: Opevněné osady lidu velatické kultury na Pavlovských vrších na jižní Moravě. Archeologické rozhledy IX, 110-112.

Řihovský, J. 1965a: Das Urnengräberfeld von Klentnice. Praha: Národní muzeum Praha.

Řihovský, J. 1965b: Průzkum sídlení oblasti lidu středodunajských popelnicových polí v Pavlovských vrších. Přehled výzkumů 1964, 39.

Řihovský, J. 1966: Průzkum v oblasti Pavlovských vrchů. Přehled výzkumů 1965, 43-44.

Říhouský, J. 1972: Die Messer in Mähren und dem Ostalpengebiet. Prähistorische Bronzefunde VII/1. München: Beck.

Řihouský, J. 1979: Die Nadeln in Mähren und im Ostalpengebiet. Prähistorische Bronzefunde XIII/5.

Řihovský, J. 1982: Základy středodunajských popelnicových polí na Moravě. Studie Archeologického ústavu Brno X/1. München: Beck.

Řihovský, J. 1992: Die Äxte, Beile, Meissel und Hämmer in Mären. Prähistorische Bornzefunde IX/17. Stuttgart: Steiner.

Salaš, M. 1987: Zur Frage der jungbronzezeitlichen Höhensiedlungen in Südmähren. In: Die Urnenfelderkulturen Mitteleuropas. Symposium Liblice 21.-25. 10. 1985. Praha, 277-286.

Schirmeisen, K. 1938: Zu den ältesten Nachrichten über Vorgeschichtsfunde bei Klentnitz nächst Nikolsburg. Zeitschrift des Deutschen Vereins für die Geschichte Mährens un Schlesiens (Brünn), 40, 69-72.

Smrž, Z. 1987: Vývoj a struktura osídlení v mikroregionu Lužického potoka na Kadaňsku. Archeologické rozhledy XXXIX, 601-621.

Stockhammer, P. W. - Massy, K. - Knipper, C. - Friedrich, R. - Kromer, B. - Lindauer, S. - Radosavljević. J. - Wittenborn, F. - Krause, J. 2015: Rewriting the Central European Early Bronze Age Chronology: Evidence from Large-Scale Radiocarbon Dating. PLoS ONE 10/10, e0139705. Available online: https://doi.org/10.1371/journal.pone.0139705

Stuchlik, S. 1972: Moravská únětická sídliště. Nepub. disertační práce. Brno: Univerzita Jana Evangelisty Purkyně.

Stuchlik, S. 1979: K poznání vzniku a staršího vývoje lidu středodunajské mohylové kultury na jižní Moravě. Nepub. kandidátská disertační práce. Brno: Archeologický ústav Československé akademie věd Brno.
Stuchlik, S. 1981: Depot středodunajské mohylové kultury z Mušova. Archeologické rozhledy XXXIII, 361-371.

Stuchliková, J. - Stuchlik, S. 1982: Osídlení Turoldu na konci eneolitu a v době bronzové. Sborník prací filosofické fakulty brněnské univerzity E 27, 91-102.

Stuchlik, S. 1984: K datování konce věteřovského osídlení na Moravě. Archeologické rozhledy XXXVI, 173-186.

Stuchlik, S. 1987: Únětické pohřebiště v Mušově. Studie Archeologického ústavu Brno XIV/2.

Stuchlik, S. 1992: Pohřebiště únětické kultury z Pavlova, okr. Břeclav. Pravěk Nová řada 2, 237-253.

Stuchlik, S. 1993: Únětická kultura. In: V. Podoborský (ed.): Pravěké dějiny Moravy, Brno: Muzejní a vlastivědná společnost, 238-257

Stuchlik, S. (ed.) 2002: Oblast vodního díla Nové Mlýny od pravěku do středověku. Brno: Archeologický ústav Akademie věd Brno.

Stuchlik, S. 2006a: Únětické hroby z Horních Věstonic. Acta Archaeologica Opaviensia 2. Opava: ÚHM FPF SUO, 165-178.

Stuchlik, S. 2006b: Borotice - mohylové pohřebiště z doby bronzové. Brno: Archeologický ústav AV ČR Brno.

Stuchlik, S. 2007: Pohřby v nádobách v době bronzové na Moravě. Študijné zvesti Archeologického ústavu Slovenskej akadémie vied 42, 197-210.

Stuchlik, S. 2018: Nový typ zlatých vlasových ozdob z Moravy. In: J. Bátora - R. Kujovský - M. Ruttkay - J. Vladár: Antont Točík, legenda slovenskej archeológie, 161-168.

Stuchliḱová, J. 1988: Starobronzové nálezy z Hodonic ve sbírkách Moravského muzea v Brně. Acta musei Moraviae LXXIII, 29-43.

Stuchliková, J. 1990: Otázky pohřebního ritu moravské věteřovské skupiny. In: V. Nekuda: Pravěké a slovanské osídlení Moravy. Brno: Archeologický ústav Brno, 146-157.

Stuchliková, J. 1993: Věteřovská skupina. In: V. Podborský (ed.): Pravěké dějiny Moravy. Brno: Muzejní a vlastivědná společnost, 262-272.

Stuchliková, J. 1999: Věteřovské sídliště v Lovčičkách (okr. Vyškov). Pravěk Nová řada 9. 301-319.

Šabatová, K. - Parma, D. 2019: Pohřbívání v závěru starší doby bronzové na Moravě: chronologie, ty- 
pologie a absolutní data. Archeologické rozhledy LXXI, 3-26.

Šabatová, K. - Parma, D. - Trampota, F. - Jarošová, I.

- Kañáková, L. - Príchystal, A. - Vargová, L. - Vymazalová, K. 2020: Archeologické rozhledy LXXII, 194-237.

Tihleka, K. 1953: Moravská únětická pohřebiště. Památky archeologické XLIV, 229-328.

Trampota, F. 2012: Mikulov (okr. Břeclav). Přehled výzkumů 53, 168.
Unger, J. 1971a: Objev vyloupeného kostrového hrobu únětické kultury v Mikulově (okr. Břeclav), Přehled výzkumů 1970, 24.

Unger, J. 1971b: Porušený hrob z doby bronzové u Mikulova (okr. Břeclav), Přehled výzkumů 1970, 24.

Unger, J. 1985: Přírůstky archeologického pracoviště Regionálního muzea v Mikulově v letech 1974-1983.

Wells-Weyrauch, U. 1978: Die Anhänger und Halsringe in Südwestdeutschland und Nordbayern. Prähistorische Bronzefunde XI/1. München: Beck. 


\section{Schola-type structures in Pompeii - a symbol and display of the power of pompeian aristocracy on the examples of structures designed for rest}

The micro-region around the Pavlov Hills, also called Pálava, forms a natural communication corridor in the eastern-western direction, which is dominated by a prominent and well-visible geomorphological landmark in the form of the limestone klippen of the Pavlov Hills (Fig. 1). The area has attracted human societies from the Upper Palaeolithic at the latest. The region in the surroundings of Pavlov Hills is one of the best explored areas in our country due to a rich history of archaeological activities. An important role in exploration of the micro-region was played by the build-up of the Nové Mlýny reservoir in 1975-1988. The collected information enables to study the Early and Middle Bronze Age settlement structure in a micro-region, which counted among significant communication nodes and sought-after settlement regions in prehistoric times.

The numerous archaeological sites situated in the construction area of the Nové Mlýny reservoir were comprehensively published by Stanislav Stuchlík (Stuchlik 2002). On the other hand, the Early and Middle Bronze Age finds from archaeological excavations conducted in the Pavlov Hills in the 1950s (cadastral districts of the municipalities Klentnice and Perná) were published only partly or not at all. The aim of the study is to present the finds from Pálava, supplement them with the newest detections from recent surveys and to put the presented data into the context of all known Early and Middle Bronze Age sites in the micro-region of the Pavlov Hills.

Among the most significant unpublished finds are inhumation graves from the Tumulus Period in the cemetery at Klentnice (Figs. 2-5). In the cadastral district of Klentnice we know of at least 3 other funerary areas from the Tumulus Period. Among the most significant settlement sites is the hilltop settlement on the hill Tabulová hora, which is well-known for many finds from the Urnfield Period (Naurátil Biško - Tencer 2020). The Early Bronze Age is represented by a small number of ceramic finds (Fig. 8: A) and probably also by two hoards of golden hair ornaments (Stuchlik 2018). The site was then enclosed in the Middle Bronze Age but the traces of an intensive use are absent. Evidence of activities from the Early and Middle Bronze Age was also acquired by surface survey of the neighbouring hilltop site Perná - Kotel and other sites in close vicinity (Fig. 9).

The data from the Pavlov Hills and from their wide surroundings were put together with the aim to follow up the settlement development and structure in the micro-region during the Early and Middle Bronze Age. From a quantitative perspective, the most frequently represented component is that of the Únětice Culture (46 sites), followed by the Věteřov Group (36 sites) and finally by the Tumulus Culture (33 sites). The Únětice component outnumbers the Věteřov component in the number of cemeteries/ graves (19:5), but the number of settlements in these two components is very similar (22:19). The balanced number of settlements does not fit into the contemporary idea of a distinctly longer duration of the Únětice Culture (ca. 2200-1750 BC) in comparison to the Věteřov Group (1750-1600 BC). This information, together with current radiocarbon dates, indicates the possibility of a longer duration of the Věteřov Group (Peška 2012; Peška 2019).

In the micro-region we can identify several settlement kernels, which are formed by local clusters of components (Fig. 11). Some kernels show a continuity from the Early to the Middle Bronze Age, others do not. Special attention should be paid to a distinct cluster of sites in cadastral districts of the municipalities Pasohlávky and Mušov, which indicates a strong connection of Únětice-Culture sites to the enclosed hilltop settlement at Mušov-Burgstall. However, we currently know very little about this Únětice-Culture site with the potential of central significance (Komoróczy - Červák - Musil 1997).

The continuity at the level of individual sites (common occurrence of consecutive chronological components) is rather a rare phenomenon, which is manifested more distinctly between the Unětice and Věteřov components and only exceptionally between the Věteřov and Tumulus components. 
Spatial data refer to specific characteristics of the settlement kernel in the area of the Pavlov Hills. Archaeological finds from the cadastral districts of Klentnice and Perná prove that the Pavlov Hills and their immediate surroundings were populated in both Early and Middle Bronze Age. However, the character of these activities remains unclear. Settlement activities are manifested very weakly, whereas finds connected with reverent and votive practices are clearly evident. These detections are in contrast to the settlement structure in lower-situated locations along the river Dyje and along smaller watercourses, where typical lowland settlements are frequently re- presented and they distinctly outnumber the funerary component.

Considering the character of Early and Middle Bronze Age relics in the Pavlov Hills and their conspicuous geomorphology, it is possible to interpret the area as an actively used sacred landscape. The connection of sacred and symbolical activities to distinct geomorphological landmarks and special elements in the landscape is a well documented phenomenon in both archaeological and historical sources (Bradley 2017, 160 ff.). The surroundings of the Pavlov Hills then represented a typical settlement and agricultural landscape. 
Navrátil

Starší a střední doba bronzová na Pavlovských vrších a v jejich okolí

Mgr. Aleš Navrátil, Ph.D.

- Muzeum města Brna

Špilberk 210/1, 66224 Brno, Česká republika

navratil@spilberk.cz 